\title{
A Statistical Review of the Oxygen Data from the Gas Generation Tests Supporting the Revision of the 9975 SARP
}

by

T. B. Edwards

Westinghouse Savannah River Company

Savannah River Site

Aiken, South Carolina 29808

DOE Contract No. DE-AC09-96SR18500

This paper was prepared in connection with work done under the above contract number with the U.S. Department of Energy. By acceptance of this paper, the publisher and/or recipient acknowledges the U.S. Government's right to retain a nonexclusive, royalty-free license in and to any copyright covering this paper, along with the right to reproduce and to authorize others to reproduce all or part of the copyrighted paper. 


\section{A Statistical Review OF THE OXYGen DATA FROM THE GAS GENERATION TESTS SUPPORTING THE REVISION OF THE 9975 $\operatorname{SARP}(\mathbf{U})$}

T. B. Edwards

Westinghouse Savannah River Company

Savannah River Technology Center Aiken, SC 29808

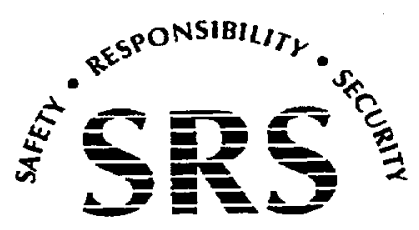

SAVANNAH RIVER SITE

PREPARED FOR THE U.S. DEPARTMENT OF ENERGY UNDER CONTRACT NO. DE-AC09-96SR18500 
WSRC-RP-99-00595

Revision 0

\section{DISCLAIMER}

This report was prepared as an account of work sponsored by an agency of the United States Government. Neither the United States Government nor any agency thereof, nor any of their employees, makes any warranty, express or implied, or assumes any legal liability or responsibility for the accuracy, completeness, or usefulness of any information, apparatus, product or process disclosed, or represents that its use would not infringe privately owned rights. Reference herein to any specific commercial product, process or service by trade name, trademark, manufacturer, or otherwise does not necessarily constitute or imply its endorsement, recommendation, or favoring by the United States Government or any agency thereof. The views and opinions of authors expressed herein do not necessarily state or reflect those of the United States Government or any agency thereof.

This report has been reproduced directly from the best available copy.

Available for sale to the public, in paper, from: U.S. Department of Commerce, National Technical Information Service, 5285 Port Royal Road, Springfield, VA 22161, phone: (800) 553-6847

fax: (703) 605-6900

email: orders@ntis.fedworld.gov

online ordering: http://www.ntis.gov/ordering.htm

Available electronically at http://www.doe.gov/bridge

Available for a processing fee to U.S. Department of Energy and its contractors, in paper, from: U.S. Department of Energy, Office of Scientific and Technical Information, P.O. Box 62, Oak Ridge, TN 37831-0062, phone: (865) 576-8401

fax: (865) 576-5728

email: reports@adonis.osti.gov 


\section{DISCLAIMER}

Portions of this document may be illegible in electronic image products. Images are produced from the best available original document. 


\section{A Statistical Review OF THE OXYGEN DATA FROM THE GAS GENERATION TESTS SUPPORTING THE REVISION OF THE 9975 SARP (U)}

T. B. Edwards

July 15, 1999

Document Approvals

2homas
T. B. Edwards, Author
Statistical Consulting Section


Revision 0

This page intentionally left blank. 


\section{INTRODUCTION}

The Chemical and Hydrogen Technology Section (CHT) of the Savannah River Technology Center (SRTC) has conducted a series of gas generation tests in support of the revision of the safety analysis report for packaging (SARP) for the 9975 container, developed at the Savannah River Site (SRS). The Packaging and Transportation Group of SRTC is coordinating the revision to this SARP. A Task Technical and Quality Assurance Plan directing this work was issued by CHT in February 1999 [1].

Initially, the primary interest in this testing was hydrogen generation. From [1], these gas "generation tests can be tracked in real-time by measuring the pressure of a sealed container of the materials being studied. Because multiple gas phase reactions are produced in the radiation field of the sample, material pressure measurements do not necessarily define the quantity of $\mathrm{H}_{2}$ generated. However, the change in total molecules of gas can be calculated using the ideal gas law from the pressure measurement, known container volume and sample temperature. A measurement of the actual headspace gases must be completed to calculate the $\mathrm{H}_{2}$ generation rate for a particular sample."

As the results from these tests were reviewed, however, questions arose regarding the oxygen in the headspace gases. Specifically, do the data from some tests indicate that oxygen was generated for those tests? And do the data for other tests indicate that the oxygen was depleted for them? A statistical analysis of the oxygen data derived from these tests is provided in this report to help answer these questions.

This analysis was conducted using JMP® Version 3.2.2, a commercial software package of the SAS Institute, Inc., in Cary, NC [2].

\section{DISCUSSION}

In this section various plots of the oxygen data are reviewed; the tests are grouped into similar types of experiments, which are then studied; measurement and analytical uncertainties are propagated through the equations used to determine the change in oxygen; and finally, the test results are judged for significant $\mathrm{O}_{2}$ changes based upon their corresponding uncertainties. As part of this final assessment, the results from those tests that are thought to be most representative of the operational window for the 9975 package are summarized.

The data from these tests are provided in Table A1 of the Appendix. A test identifier is provided in the first column of this table. This identifier is used throughout this report to designate specific tests. Table A2 in the Appendix provides additional information for these tests designated using these same test identifying numbers. 
As described above for $\mathrm{H}_{2}$, the determination of interest for $\mathrm{O}_{2}$ is the change in total $\mathrm{O}_{2}$ molecules from the beginning to the end of each test in the sample vessel.

This determination is made using the following equation

$$
\mathrm{r}=\mathrm{n}_{2}-\mathrm{n}_{1}=\frac{\mathrm{mP}_{2} \mathrm{~V}}{\mathrm{RT}_{2}}-\frac{\mathrm{aP}_{1} \mathrm{~V}}{\mathrm{RT}_{1}}
$$

where $\mathrm{n}_{1}$ is an estimate of the initial moles of $\mathrm{O}_{2}$ in the headspace gases of the container and $\mathrm{n}_{2}$ is an estimate of the final moles of $\mathrm{O}_{2}$ in the headspace gases. Equation (1) also shows how these estimates are determined using the ideal gas law. In equation (1), the term "a" represents the initial $\mathrm{O}_{2}$ as a fraction of the headspace gas volume, $\mathrm{V}$ (in cubic centimeters, $\mathrm{cc}$ ), at an initial pressure of $\mathrm{P}_{1}$ (in torr) and temperature of $T_{1}$ (in degrees Kelvin, ${ }^{\circ} \mathrm{K}$ ). $\mathrm{R}$ is the universal gas constant, $62324.73 \frac{\text { torr } \cdot \mathrm{cc}}{\mathrm{K} \cdot \mathrm{mole}}$. The " $\mathrm{m}$ " term in equation (1) represents the final $\mathrm{O}_{2}$ concentration as a fraction of the headspace gases of volume $\mathrm{V}$ at a pressure of $\mathrm{P}_{2}$ (in torr) and temperature $\mathrm{T}_{2}\left({ }^{\circ} \mathrm{K}\right)$.

The value of "a" for each experiment is the fraction of $\mathrm{O}_{2}$ in air, for which the reference value is 0.20946 . The value for " $\mathrm{m}$ " was determined by gas chromatography utilizing a sample of the headspace gases taken by syringe at the end of the test. These values along with results from equation (1) are provided in Table A1.

\section{INITIAL LOOK AT THE OXYGEN DATA}

Exhibit A1 in the Appendix provides a plot of the initial $\mathrm{O}_{2}$ molar value versus the corresponding final value by test. Some of those tests with final $\mathrm{O}_{2}$ values larger than their initial values are labeled with their test number in this plot. Exhibit A2 in the Appendix provides a plot of the change in $\mathrm{O}_{2}$ (final minus initial) by test number. A reference line at zero is also shown on this plot. Two questions of interest in this last plot are: "Which of these test results indicate a significant increase in $\mathrm{O}_{2}$ (if any)?" and "Which of these tests indicate a significant decrease in $\mathrm{O}_{2}$ (if any)?"

In order to answer these questions, an idea of the repeatability of the outcomes from similar tests must be determined. The test descriptions in Table A2 of the Appendix were used to group the tests into the categories indicated in Table 1.

Table 1: Types of Tests

\begin{tabular}{|c|c|}
\hline Type & Tests \\
\hline $\mathrm{PuO} 2+\mathrm{MgO}$ & $1,11,23 \mathrm{H}, 25,26$ \\
\hline $\mathrm{PuO} 2+\mathrm{CaF}$ & $9,14,19$ \\
\hline $\mathrm{Pu}$ Cake & $17,44,50,52$ \\
\hline $\mathrm{PuO} 2$ & $12,16 \mathrm{H}, 41,51$ \\
\hline $\mathrm{PuO} 2+\mathrm{CaO}$ & $2,8,15 \mathrm{H}$ \\
\hline & $3,4,5,6,7,10,13,18,20,21,22,24,28,29,30,31,32$, \\
Other & $33,34,35,36,37,38,39,40,41,42,43,45,46,47,48$, \\
& $49,53,54,55,56,57,58,59$ \\
\hline
\end{tabular}


An " $\mathrm{H}$ " following a test number indicates that that particular test was heated, possibly differentiating it from the other tests in its group.

Exhibit $\mathrm{A} 3$ in the Appendix provides a look at the change in $\mathrm{O}_{2}$ by group type. Descriptive statistics for each of these groups are also provided in this exhibit. Note that the heated tests (those with the " $\mathrm{H}$ " suffix in Table 1) are labeled (in addition to those that were labeled earlier) in this exhibit and that they result in a change in $\mathrm{O}_{2}$ that appears to be different from their unheated counterparts. The average and standard deviation of each group containing a heated test are computed including and excluding this test.

The repeatability of a test of the 9975 package may be represented by the standard deviation in the measurements of set of identical experiments. Each of the first 5 groups from Table 1 (excluding the heated tests) is to be considered as a set of nearly identical experiments. Their standard deviations range from 0.000071 to 0.000002 moles of $\mathrm{O}_{2}$ with a pooled estimate of the standard deviation across all five groups of 0.00004 moles. When considered on a percentage basis as a relative (to the mean $\mathrm{O}_{2}$ change) standard deviation, they range from about $21 \%$ to about $101 \%$ of the average $\mathrm{O}_{2}$ change for the group with a pooled relative standard deviation of about $88 \%$ (using a one-way analysis of variance approach). In summary, a 2-sigma uncertainty determined from these results would be lead to a limit of $+/-0.00008$ moles and $+/-176 \%$ of reading for absolute and relative errors, respectively. ${ }^{1}$ Obviously, assessing the $\mathrm{O}_{2}$ changes using the relative errors leads to insignificant differences between the initial and final oxygen for all of the tests. For those tests showing a potential $\mathrm{O}_{2}$ increase, the absolute error 2sigma limit leads to only 28,48 , and 49 being significant at an approximate $95 \%$ confidence level.

Part of the variation seen among the results for each of these groups is from measurement and analytical uncertainty and part is from differences in the conditions among each set of repeated tests (i.e., the conditions of the tests in each group may not have been as "identical" as desired). The next section looks at the variation due to the first of these two categories via the approach of error propagation. Before moving on to that topic, consider two additional looks at these data.

The first is a plot of the $\mathrm{O}_{2}$ change versus headspace volume (in cc) across all of the tests, which is provided in Exhibit A4 in the Appendix. The volume of headspace gases in the container of each test is plotted along the $\mathrm{x}$-axis. Along the $\mathrm{y}$-axis the initial moles of $\mathrm{O}_{2}$ are plotted as a solid light-gray line. The final moles of $\mathrm{O}_{2}$ are also plotted on the y-axis, and their values are indicated by the symbol " $x$ ". While several of the tests showing a potential increase in $\mathrm{O}_{2}$ have a headspace gas volume in the interval from 65 to $75 \mathrm{cc}$, other tests with volumes of only $30 \mathrm{cc}$ also show a potential increase in $\mathrm{O}_{2}$. Thus, there is no obvious

Absolute and relative errors are discussed later in this section. 
relationship between the initial headspace gas volume and the generation or depletion of $\mathrm{O}_{2}$.

One of the key steps in measuring the final $\mathrm{O}_{2}$ value is injecting a sample from the headspace gas of the test container into a gas chromatograph. The recovery of this sample as reflected by its total sample volume percent determination is a critical measurement in this procedure. The target value for this determination is $100 \%$. Exhibit A5 in the Appendix provides a plot of the $\mathrm{O}_{2}$ changes versus the total sample volume percent determinations for these tests. There is no obvious relationship between the total sample volume percent determination and the generation or depletion of $\mathrm{O}_{2}$.

\section{Propagation of Measurement UnCertainties}

As evident in equation (1), the determination of $r$, the difference in moles of $\mathrm{O}_{2}$ from the beginning to the end of a test, is dependent on several measurements conducted over the course of the test. One question of interest as the results of these tests are evaluated is the potential impact of the uncertainties of these measurements on the derived values for $r$. Propagating the measurement uncertainties or errors afflicting the terms of equation (1) into the resultant $\mathbf{r}$ reveals this potential impact.

The errors in experimental measurements fall into the two broad categories of bias errors and random errors. Bias is related to accuracy, the closeness of agreement between the measured value and the true value. ${ }^{2}$ Randomness of a measurement is related to the precision or repeatability of the measurement. Appropriately taken together, these two errors yield the uncertainty of the measurement. The error propagation for equation (1) conducted here follows the framework provided in reference [3]. This reference also provides a full discussion of the practice of and underlying theory for uncertainty analysis in an experimental setting. It is a linearized approach based on the use of a Taylor series expansion of equation (1).

Using the approach and terminology of [3], a 95\% coverage estimate of the uncertainty in the result $r, U_{r}$, can be expressed as

$$
\mathrm{U}_{\mathrm{r}}^{2}=\mathrm{B}_{\mathrm{r}}^{2}+\left(\mathrm{tS}_{\mathrm{r}}\right)^{2}
$$

where $B_{r}$ represents the $95 \%$ confidence bound of the bias limit for $r, S_{r}$ represents the estimate of the standard deviation of the random errors, and $t$ is the two-tailed, 95\% Student $t$ value (i.e., the $97.5^{\text {th }}$ percentile, with degrees of freedom equal to those associated with the estimate of $S_{r}$ ).

2. In the situation where bias errors are known, the corresponding measurements are frequently corrected for these biases. Some random errors may been induced into the measurement by this process, however. In addition, the durations of the biases often vary. Some bias or systematic errors may remain constant over only a few measurements while others may afflict an entire experimental study. For this study, the approach taken is to select bounding values (at a $95 \%$ confidence level) for the potential measurement biases. 
The bias $\left(B_{r}\right)$ and precision $\left(S_{r}\right)$ errors for $r$ are estimated by propagating the bias $\left(B_{i}\right)$ and precision $\left(S_{i}\right)$ errors of each measurement term $i$ of equation (1) using a Taylor's series expansion as indicated in the following equations:

$$
B_{r}^{2}=\sum_{i=1}^{J} \theta_{i}^{2} B_{i}^{2}+2 \sum_{i=1}^{J-1} \sum_{j=i+1}^{J} \theta_{i} \theta_{j} \rho_{i j} B_{i} B_{j}
$$

and

$$
\left(t S_{r}\right)^{2}=\sum_{i=1}^{J} \theta_{i}^{2}\left(t S_{i}\right)^{2}+2 \sum_{i=1}^{J-1} \sum_{j=i+1}^{J} \theta_{i} \theta_{j} \rho_{i j}^{\prime}\left(t S_{i}\right)\left(t S_{j}\right)
$$

where the summations are over the $\mathrm{J}(=7)$ terms of equation (1), which are listed in Table 2 and which contribute uncertainty to the resultant $r$, each $\theta_{i}=\frac{\partial r}{\partial_{i}{ }^{\text {th }} \text { term }}$ represents the partial derivative of equation (1) with respect to the $i^{\text {th }}$ term of that equation, each $B_{i}$ represents the $95 \%$ confidence estimate of the bias for the $i^{\text {th }}$ such term, $S_{i}$ represents the standard deviation of the precision errors for this $i^{\text {th }}$ term, the corresponding Student $t$ value is chosen for $95 \%$ (two-tailed) confidence and reflecting the degrees of freedom associated with $S_{i}$, the $\rho_{i j}$ expression represents the correlation between the biases for terms $i$ and $j$, and the $\rho_{i j}$ expression represents the correlation between the random errors for terms $i$ and $j$.

For the approach being used here, the degrees of freedom associated with each estimated $S_{i}$ is assumed large enough to justify using $t=2$ in the analyses that follow.

Table 2 provides a list of the partial derivative of equation (1) with respect to each term of interest and provides initial estimates of the bias and precision errors for each of these terms. 
Table 2: Information Associated with the Propagation of Errors

\begin{tabular}{|c|c|c|c|c|c|c|c|}
\hline \multicolumn{2}{|c|}{ Term } & Units & Partial Derivative & $\begin{array}{c}95 \% \text { Bound for } \\
\text { Bias, } \mathbf{B}_{i} \\
\text { (relative) }\end{array}$ & $\begin{array}{c}95 \% \text { Bound for } \\
\text { Bias, } B_{i} \\
(\text { absolute) }\end{array}$ & $\begin{array}{c}\text { 1 Standard } \\
\text { Deviation } \\
\text { Precision, } S_{i} \\
\text { (relative) }\end{array}$ & $\begin{array}{c}\text { 1 Standard } \\
\text { Deviation } \\
\text { Precision, } \\
\text { (absolute) }\end{array}$ \\
\hline 1 & $\mathrm{a}$ & & $\frac{-\mathrm{P}_{1} \cdot \mathrm{V}}{\mathrm{R} \cdot \mathrm{T}_{1}}$ & $2 \%$ & 0.004 & $2 \%$ & 0.004 \\
\hline 2 & $\mathrm{~V}$ & $\mathrm{cc}$ & $\frac{\mathrm{m} \cdot \mathrm{P}_{2}}{\mathrm{R} \cdot \mathrm{T}_{2}}-\frac{\mathrm{a} \cdot \mathrm{P}_{1}}{\mathrm{R} \cdot \mathrm{T}_{1}}$ & $3 \%$ & 1 & $3 \%$ & 1 \\
\hline 3 & $\mathrm{~m}$ & & $\frac{\mathrm{P}_{2} \cdot \mathrm{V}}{\mathrm{R} \cdot \mathrm{T}_{2}}$ & $5 \%$ & 0.01 & $5 \%$ & 0.01 \\
\hline 4 & $\mathrm{P}_{1}$ & torr & $\frac{-\mathrm{a} \cdot \mathrm{V}}{\mathrm{R} \cdot \mathrm{T}_{1}}$ & $1 \%$ & 7 & $1 \%$ & 7 \\
\hline 5 & $\mathrm{P}_{2}$ & torr & $\frac{\mathrm{m} \cdot \mathrm{V}}{\mathrm{R} \cdot \mathrm{T}_{2}}$ & $1 \%$ & 7 & $1 \%$ & 7 \\
\hline 6 & $\mathrm{~T}_{1}$ & ${ }^{\mathrm{o}} \mathrm{K}$ & $\frac{\mathrm{a} \cdot \mathrm{P}_{1} \cdot \mathrm{V}}{\mathrm{R} \cdot \mathrm{T}_{1}^{2}}$ & $0.33 \%$ & 1 & $0.33 \%$ & 1 \\
\hline 7 & $\mathrm{~T}_{2}$ & ${ }^{\circ} \mathrm{K}$ & $\frac{-\mathrm{m} \cdot \mathrm{P}_{2} \cdot \mathrm{V}}{\mathrm{R} \cdot \mathrm{T}_{2}^{2}}$ & $0.33 \%$ & 1 & $0.33 \%$ & 1 \\
\hline
\end{tabular}

The estimates of the uncertainties presented in Table 2 will be the basis for deriving the uncertainties, via error propagation, for the r's resulting from these 9975 package tests. ${ }^{3}$ As indicated in this table, relative and absolute errors will be considered in this analysis for each measurement.

There is a need to understand the difference between using relative and absolute errors to represent or model these uncertainties. Let the true value for a measurement be represented by $M_{T}$. If the size of the errors afflicting $M_{T}$ is affected by the size of $\mathbf{M}_{\mathrm{T}}$ itself, then the use of relative errors would be appropriate. If the size of the errors is unaffected by the size of $\mathrm{M}_{\mathrm{T}}$, then the use of absolute errors is appropriate.

For example, the value of the sample volume, V, varies from a low of $14.43 \mathrm{cc}$ to a high of $123.67 \mathrm{cc}$ over these tests. The bias, when considered as a relative $3 \%$ error, would range from $14.43 \times 0.03=0.433 \mathrm{cc}$ to $123.67 \times 0.03=3.71 \mathrm{cc}$. The bias, when considered as an absolute error, would be a constant $1 \mathrm{cc}$. The standard deviation of the random errors afflicting $\mathrm{V}$, when considered as a relative error, would range from $14.43 \times 0.03=0.433 \mathrm{cc}$ to $123.67 \times 0.03=3.71 \mathrm{cc}$. The standard deviation would be a constant (an absolute) $1 \mathrm{cc}$ when these random errors are assumed to be unaffected by the size of $\mathrm{V}$.

It is not unusual for the absolute errors to dominate when $\mathrm{M}_{\mathrm{T}}$ is at the low end of the range of its possible values while relative errors dominate when $\mathrm{M}_{\mathrm{T}}$ is at the high end of its range. In the discussion that follows, error propagations are conducted that consider various combinations of these errors as relative or absolute, since the true models for these uncertainties are not known.

3 These estimates of bias and precision were developed during discussions of these issues and are felt to be representative of these measurement uncertainties. 
Correlations among the biases and any among the random errors afflicting the measurements for any one test would be limited to the beginning and ending temperatures and the beginning and ending pressures. It is expected that such correlations would be positive in sign. Note, however, that the partial derivatives for the two pressures and those for the two temperatures are of different signs. This implies that any such correlations among these biases and/or among these random errors would tend to reduce the uncertainty of the resultant, $r$.

\section{SIGNIFICANT DIFFERENCES IN MOLES OF OXYGEN}

In the analyses that follow, the focus is on two primary situations. The first assumes that there are no correlations among these measurements and that the uncertainties of Table 2 are representative. In this situation, the error propagation is to be developed (i.e., the choice between each relative and absolute error model is made) to provide an upper bound on the uncertainties for the $r$ values (at a 95\% confidence level). The second situation reflects highly correlated errors between the two temperature measurements, highly correlated errors between the two pressure measurements, and uncertainties for all measurements smaller than those appearing in Table 2. The intent is to use the second situation to conduct a sensitivity analysis on the assumptions used in the first situation.

Table 3 provides the results for the first situation, the upper bounding case. It identifies each of the 9975 package tests, provides values for the 7 measurement terms from equation (1), evaluates the corresponding value for $r$, and propagates the uncertainties of the measurements into the resulting $r$, selecting the maximum of the relative and absolute error models for each measurement. No correlations among the biases or random errors are considered in this table.

The next to the last column of this table provides the uncertainty of the measured difference, $\mathrm{r}$, in $\mathrm{O}_{2}$, at a $95 \%$ confidence level. This is a $+/$ - uncertainty for the derived value of $r$. The last column indicates the results of assessing the difference between the calculated value of $r$ and zero in light of $r$ 's uncertainty. Three labels are used for the rows of this last column. If the value of $r$ is sufficiently greater than zero, the label " $\mathrm{O}_{2}$ generated" is used for the row. If the value of $\mathrm{r}$ is sufficiently less than zero, the label used is " $\mathrm{O}_{2}$ depleted." Otherwise, the label "No difference" is used for the row.

Exhibit A6 in the Appendix provides a plot of the results of Table 3 by test. It shows the upper and lower error bounds for each test plotted around zero. If the calculated value of $r$ falls within this interval, there is no significance difference between the initial and final moles of $\mathrm{O}_{2}$. A plotted value about the upper limit, indicates that the final moles of $\mathrm{O}_{2}$ is significantly greater than the initial for that test, and a plotted value below the lower limit indicates that the final $\mathrm{O}_{2}$ moles are significantly less than the initial moles. Thus, this plot provides a graphical representation of the significance of the $\mathrm{O}_{2}$ difference relative to the $95 \%$ uncertainty limits. 


\section{Revision 0}

Table 3: Results of Bounding Error Propagation by Test Number

\begin{tabular}{|c|c|c|c|c|c|c|c|c|c|c|c|}
\hline & & & & & & & & & & $95 \%$ & r value \\
\hline & & & & & & & & & & Uncertainty & relative to \\
\hline Test & a & P1 & $\mathbf{V}$ & T1 & $\mathbf{m}$ & $\mathbf{P 2}$ & T2 & $\mathbf{R}$ & $\mathbf{r}$ & for $\mathbf{r}$ & zero at $95 \%$ \\
\hline 1 & 0.20946 & 752.2 & 34.11 & 296.6 & 0.188 & 743.2 & 295.7 & 62324,73 & -0.000032 & 0.00003470 & No difference \\
\hline 2 & 0.20946 & 741.9 & 63.86 & 294.7 & 0.179 & 711.8 & 297.2 & 62324.73 & -0.000101 & 0.00006254 & $\mathrm{O}_{2}$ Depleted \\
\hline 3 & 0.20946 & 740.9 & 30.50 & 299.3 & 0.211 & 741.3 & 295.9 & 62324.73 & 0.000005 & 0.00003222 & No difference \\
\hline 4 & 0.20946 & 748.3 & 30.90 & 298.5 & 0.201 & 751.5 & 295.4 & 62324.73 & -0.000007 & 0.00003182 & No difference \\
\hline 5 & 0.20946 & 755.5 & 29.81 & 297.3 & 0.228 & 891.3 & 295.5 & 62324.73 & 0.000074 & 0.00004012 & $\mathrm{O}_{2}$ Generated \\
\hline 6 & 0.20946 & 775.7 & 62.33 & 295.5 & 0.039 & 774.7 & 294.5 & 62324.73 & -0.000447 & 0.00007169 & $\mathrm{O}_{2}$ Depleted \\
\hline 7 & 0.20946 & 649.4 & 49.71 & 296.2 & 0.036 & 808.1 & 331.0 & 62324.73 & -0.000296 & 0.00005145 & $\mathrm{O}_{2}$ Depleted \\
\hline 8 & 0.20946 & 750.2 & 64.10 & 295.6 & 0.196 & 735.1 & 295.7 & 62324.73 & -0.000046 & 0.00006467 & No difference \\
\hline 9 & 0.20946 & 734.5 & 62.91 & 299.1 & 0.202 & 733.3 & 298.2 & 62324.73 & -0.000018 & 0.00006303 & No difference \\
\hline 10 & 0.20946 & 746.5 & 43.46 & 298.5 & 0.202 & 746.5 & 295.8 & 62324.73 & -0.000010 & 0.00004463 & No difference \\
\hline 11 & 0.20946 & 755.7 & 38.51 & 296.4 & 0.197 & 749.7 & 295.9 & 62324.73 & -0.000022 & 0.00003948 & No difference \\
\hline 12 & 0.20946 & 756.6 & 30.72 & 297.5 & 0.2 & 753.7 & 296.1 & 62324.73 & -0.000012 & 0.00003161 & No difference \\
\hline 13 & 0.20946 & 762.3 & 51.66 & 302.1 & 0.031 & 655.9 & 295.9 & 62324.73 & -0.000381 & 0.00005323 & $\mathrm{O}_{2}$ Depleted \\
\hline 14 & 0.20946 & 765.1 & 64.37 & 296.3 & 0.167 & 975.2 & 329.5 & 62324.73 & -0.000048 & 0.00007500 & No difference \\
\hline 15 & 0.20946 & 754.1 & 65.63 & 299.6 & 0.117 & 806.3 & 327.6 & 62324.73 & .0 .000252 & 0.00006695 & $\mathrm{O}_{2}$ Depleted \\
\hline 16 & 0.20946 & 760.2 & 30.78 & 296.1 & 0.155 & 753.2 & 314.3 & 62324.73 & -0.000082 & 0.00003058 & $\mathrm{O}_{2}$ Depleted \\
\hline 17 & 0.20946 & 762.2 & 42.04 & 298.0 & 0.206 & 779.1 & 297.2 & 62324.73 & 0.000003 & 0.00004546 & No difference \\
\hline 18 & 0.20946 & 760.0 & 30.34 & 298.0 & 0.155 & 1179.8 & 296.4 & 62324.73 & 0.000040 & 0.00004593 & No difference \\
\hline 19 & 0.20946 & 751.7 & 52.40 & 298.4 & 0.182 & 744.5 & 297.4 & 62324.73 & -0.000061 & 0.00005307 & $\mathrm{O}_{2}$ Depleted \\
\hline 20 & 0.20946 & 753.4 & 53.82 & 297.6 & 0 & 1178.3 & 321.3 & 62324.73 & -0.000458 & 0.00008059 & $\mathrm{O}_{2}$ Depleted \\
\hline 21 & 0.20946 & 744.0 & 25.98 & 298.4 & 0.06 & 803.2 & 323.0 & 62324.73 & -0.000155 & 0.00002898 & $\mathrm{O}_{2}$ Depleted \\
\hline 22 & 0.20946 & 749.4 & 43.03 & 298.3 & 0.154 & 742.1 & 298.0 & 62324.73 & -0.000099 & 0.00004357 & $\mathrm{O}_{2}$ Depleted \\
\hline 23 & 0.20946 & 758.2 & 31.95 & 299.0 & 0.119 & 806.3 & 307.8 & 62324.73 & -0.000112 & 0.00003417 & $\mathrm{O}_{2}$ Depleted \\
\hline 24 & 0.20946 & 764.4 & 43.83 & 298.1 & 0.197 & 764.3 & 297.8 & 62324.73 & -0.000022 & 0.00004545 & No difference \\
\hline 25 & 0.20946 & 749.5 & 14.43 & 295.9 & 0.126 & 800.2 & 324.7 & 62324.73 & -0.000051 & 0.00001633 & $\mathrm{O}_{2}$ Depleted \\
\hline 26 & 0.20946 & 752.6 & 25.67 & 296.2 & 0.162 & 789.2 & 317.1 & 62324.73 & -0.000053 & 0.00002617 & $\mathrm{O}_{2}$ Depleted \\
\hline 28 & 0.20946 & 758.2 & 68.91 & 296.7 & 0.242 & 829.8 & 297.9 & 62324.73 & 0.000153 & 0.00009085 & $\mathrm{O}_{2}$ Generated \\
\hline 29 & 0.20946 & 768.4 & 27.47 & 371.7 & 0.133 & 341.5 & 419.5 & 62324.73 & -0.000143 & 0.00001726 & $\mathrm{O}_{2}$ Depleted \\
\hline 30 & 0.20946 & 755.8 & 63.26 & 297.8 & 0.165 & 724.6 & 297.6 & 62324.73 & -0.000132 & 0.00006300 & $\mathrm{O}_{2}$ Depleted \\
\hline 31 & 0.20946 & 733.8 & 26.22 & 369.5 & 0.205 & 738.8 & 367.5 & 62324.73 & -0.000002 & 0.00002169 & No difference \\
\hline 32 & 0.20946 & 753.9 & 91.65 & 297.5 & 0.129 & 772.2 & 296.9 & 62324.73 & -0.000287 & 0.00009684 & $\mathrm{O}_{2}$ Depleted \\
\hline 33 & 0.20946 & 760.0 & 38.54 & 298.8 & 0.202 & 751.8 & 296.8 & 62324.73 & -0.000013 & 0.00003982 & No difference \\
\hline 34 & 0.20946 & 768.9 & 38.98 & 298.9 & 0.202 & 760.5 & 296.9 & 62324.73 & -0.000013 & 0.00004072 & No difference \\
\hline 35 & 0.20946 & 745.8 & 53.04 & 296.4 & 0.189 & 755.3 & 297.4 & 62324.73 & -0.000040 & 0.00005432 & No difference \\
\hline 36 & 0.20946 & 748.5 & 61.32 & 297.9 & 0.013 & 3843.2 & 324.5 & 62324.73 & -0.000366 & 0.00026301 & $\mathrm{O}_{2}$ Depleted \\
\hline 37 & 0.20946 & 741.6 & 26.49 & 297.4 & 0.2 & 813.1 & 316.1 & 62324.73 & -0.000003 & 0.00002739 & No difference \\
\hline 38 & 0.20946 & 744.9 & 44.90 & 297.4 & 0.141 & 802.2 & 297.9 & 62324.73 & -0.000104 & 0.00004835 & $\mathrm{O}_{2}$ Depleted \\
\hline 39 & 0.20946 & 752.4 & 46.04 & 297.4 & 0.208 & 758.3 & 297.8 & 62324.73 & 0.000000 & 0.00004889 & No difference \\
\hline 40 & 0.20946 & 759.7 & 46.27 & 297.9 & 0.201 & 805.8 & 298.0 & 62324.73 & 0.000007 & 0.00005028 & No difference \\
\hline 41 & 0.20946 & 750.0 & 19.25 & 298.2 & 0.199 & 742.32 & 296.4 & 62324.73 & -0.000009 & 0.00001952 & No difference \\
\hline 42 & 0.20946 & 751.6 & 72.90 & 301.3 & 0.197 & 739.1 & 296.9 & 62324.73 & -0.000038 & 0.00007337 & No difference \\
\hline 43 & 0.20946 & 742.4 & 70.24 & 303.0 & 0.209 & 730.8 & 296.9 & 62324.73 & 0.000001 & 0.00007241 & No difference \\
\hline 44 & 0.20946 & 750.5 & 123.67 & 300.6 & 0.186 & 722.7 & 297.4 & 62324.73 & -0.000141 & 0.00012212 & $\mathrm{O}_{2}$ Depleted \\
\hline 45 & 0.20946 & 756.9 & 37.51 & 298.5 & 0.21 & 782.5 & 297.4 & 62324.73 & 0.000013 & 0.00004130 & No difference \\
\hline 46 & 0.20946 & 763.9 & 38.12 & 298.9 & 0.211 & 788.3 & 296.9 & 62324.73 & 0.000015 & 0.00004253 & No difference \\
\hline 47 & 0.20946 & 749.7 & 18.96 & 297.9 & 0.073 & 1197.3 & 370.0 & 62324.73 & -0.000088 & 0.00002573 & $\mathrm{O}_{2}$ Depleted \\
\hline 48 & 0.20946 & 752.4 & 71.59 & 297.7 & 0.227 & 1095.2 & 336.7 & 62324.73 & 0.000240 & 0.00010292 & $\mathrm{O}_{2}$ Generated \\
\hline 49 & 0.20946 & 744.4 & 69.90 & 297.8 & 0.297 & 1092.7 & 333.9 & 62324.73 & 0.000503 & 0.00013241 & $\mathrm{O}_{2}$ Generated \\
\hline 50 & 0.20946 & 748.8 & 122.76 & 298.2 & 0.189 & 736 & 298.4 & 62324.73 & -0.000118 & 0.00012278 & No difference \\
\hline 51 & 0.20946 & 755.7 & 18.74 & 298.1 & 0.199 & 753.4 & 298.1 & 62324.73 & -0.000008 & 0.00001917 & No difference \\
\hline 52 & 0.20946 & 762.5 & 45.15 & 298.8 & 0.2014 & 747.9 & 298.4 & 62324.73 & -0.000022 & 0.00004616 & No difference \\
\hline 53 & 0.20946 & 754.9 & 18.74 & 297.6 & 0.13 & 872.6 & 338.2 & 62324.73 & -0.000059 & 0.00002052 & $\mathrm{O}_{2}$ Depleted \\
\hline 54 & 0.20946 & 754.7 & 31.56 & 298.1 & 0.2 & 775.2 & 315.6 & 62324.73 & -0.000020 & 0.00003153 & No difference \\
\hline 55 & 0.20946 & 743.3 & 71.49 & 298.4 & 0.19 & 744.9 & 298.1 & 62324.73 & -0.000054 & 0.00007213 & No difference \\
\hline 56 & 0.20946 & 759.8 & 37.50 & 298.4 & 0.2 & 774.6 & 297.5 & 62324.73 & -0.000008 & 0.00003931 & No difference \\
\hline 57 & 0.20946 & 774.9 & 18.49 & 298.3 & 0.101 & 1048.9 & 300.6 & 62324.73 & -0.000057 & 0.00002561 & $\mathrm{O}_{2}$ Depleted \\
\hline 58 & 0.20946 & 750.0 & 31.27 & 298.8 & 0.00126 & 750.3 & 299.3 & 62324.73 & -0.00000594 & 0.00003234 & No difference \\
\hline 59 & 0.20946 & 742.4 & 59.55 & 298.2 & 0.162 & 1019 & 322.6 & 62324.73 & -0.000009 & 0.00007296 & No difference \\
\hline
\end{tabular}

Table 4 repeats the conclusions from Table 3 and adds the results from three more approaches to the error propagation for equation (1). The columns of Table 4 headed "Correlations With Uncertainties" reflects the results of an error propagation using the information of Table 2 and assuming perfect positive correlations between the biases for the two pressure measurements, between the biases for the two temperature measurements, between the random errors for the two pressure measurements, and between the random errors for the two temperature measurements. The next pair of columns shows the results from the 
approach of assuming these same correlations but reducing the uncertainties of Table 2 by a factor of 2 . The last pair shows the results from the error propagation assuming these same correlations and reducing the uncertainties of Table 2 by a factor of 5 . For these correlated situations, the minimum of the relative and absolute error models is selected to represent each and every uncertainty term of equations (3) and (4) involved in the error propagation.

Table 4: Comparisons Among The Error Propagation Approaches

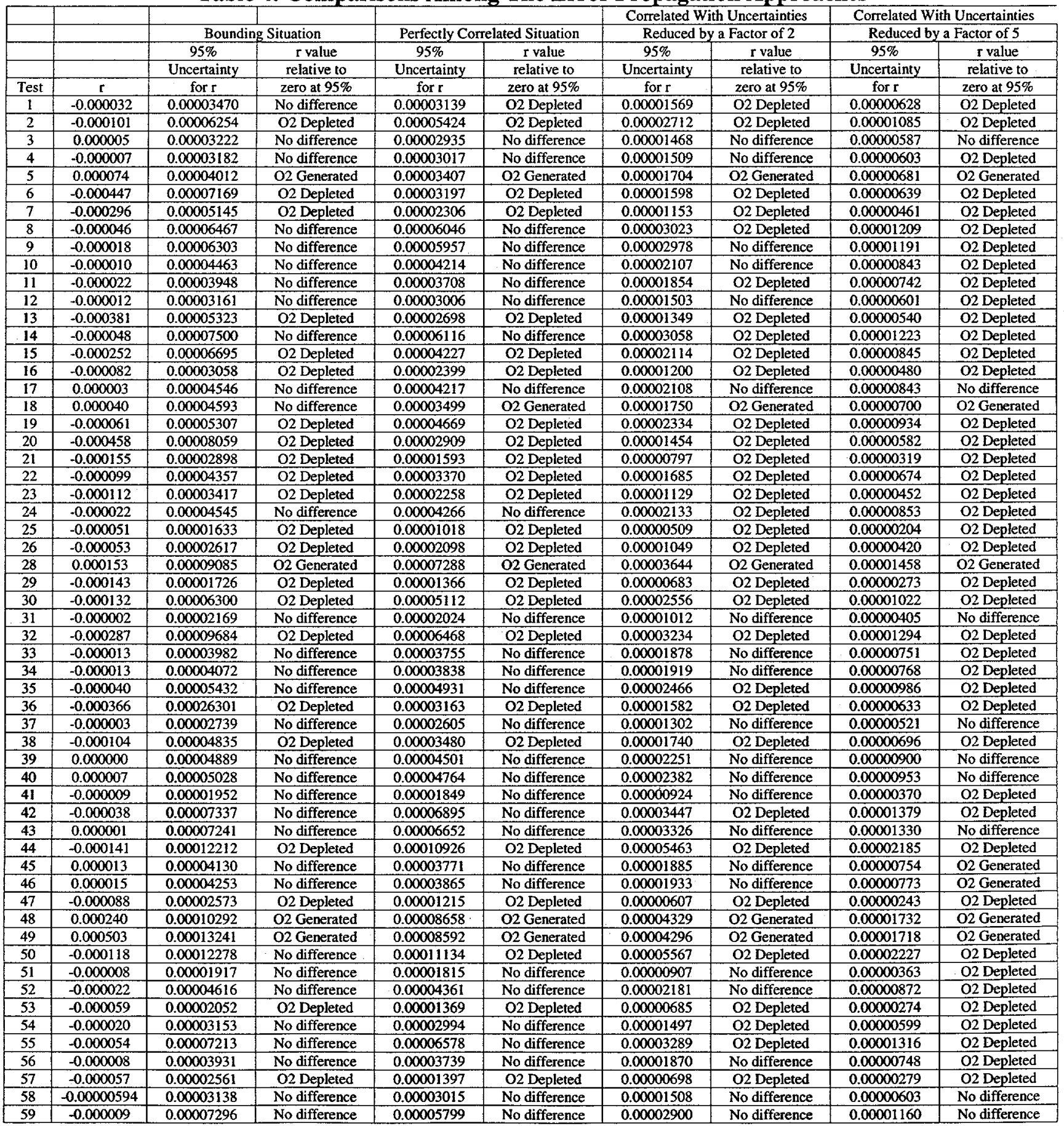


Table 5 summarizes the results from the various approaches to propagating the errors of Table 2 into equation (1). This table identifies those tests (by number) that reveal an $\mathrm{O}_{2}$ change significantly nonzero (at the $95 \%$ confidence level). The average of the uncertainties across all of the tests is also provided for each situation.

Table 5: Summary Information from Error Propagations

\begin{tabular}{|c|c|c|c|}
\hline $\begin{array}{c}\text { Description of Propagation } \\
\text { Approach }\end{array}$ & $\begin{array}{c}\text { Tests showing } \\
\text { an increased } \mathrm{O}_{2} \text { level }\end{array}$ & $\begin{array}{c}\text { Tests showing } \\
\text { a decreased } \mathrm{O}_{2} \text { level }\end{array}$ & $\begin{array}{c}\text { Average Uncertainty in } \mathrm{O}_{2} \\
\text { Change (moles) }\end{array}$ \\
\hline $\begin{array}{c}\text { Bounding Case } \\
\text { Using Maximum of Relative versus } \\
\text { Absolute Errors }\end{array}$ & $5,28,48,49$ & $\begin{array}{c}2,6,7,13,15,16, \\
19-23,25,26,29,30,32, \\
36,38,44,47,53,57\end{array}$ & 0.00005541 \\
\hline $\begin{array}{c}\text { Correlated Errors Using Minimum } \\
\text { of Relative versus Absolute Errors }\end{array}$ & $5,18,28,48,49$ & $\begin{array}{c}1,2,6,7,13,15,16,19- \\
23,25,26,29,30,32,36, \\
38,44,47,50,53,57\end{array}$ & 0.00004151 \\
\hline $\begin{array}{c}\text { Correlated Errors Using Minimum } \\
\text { of Relative versus Absolute Errors } \\
\text { with Initial Uncertainties Reduced } \\
\text { by a Factor of 2 }\end{array}$ & $5,18,28,48,49$ & $\begin{array}{c}1,2,6-8,11,13-16,19-26, \\
29,30,32,35,36,38,42, \\
44,47,50, \\
53-55,57\end{array}$ & 0.00002075 \\
\hline $\begin{array}{c}\text { Correlated Errors Using Minimum } \\
\text { of Relative versus Absolute Errors } \\
\text { with Initial Uncertainties Reduced } \\
\text { by a Factor of 5 }\end{array}$ & $5,18,28,45,46,48,49$ & $\begin{array}{c}1,2,4,6-16,19-26,29, \\
30,32-36,38,41,42,44, \\
47,50-57\end{array}$ & 0.00000830 \\
\hline
\end{tabular}

In comparing the test conditions indicated in Table A2 to the anticipated operational window for the 9975 package, several of the tests are deemed unrepresentative of the operational conditions or are considered to have led to questionable outcomes. The tests deemed unrepresentative include 29, 35, 40, 46, and 52 (due to under injection of the sample in the gas chromatography measurement), 5 and 18 (due to excessive moisture), and $28,35,42,43,48$, and 49 (due to the samples not having sand, slag, and crucible, SS\&C, components).

Exhibit A7 in the Appendix provides a plot the $\mathrm{O}_{2}$ changes for those remaining tests that are considered to be representative of the 9975-package operational conditions. Also, shown on this plot are the corresponding upper uncertainty limits for these oxygen differences. This plot shows that none of these tests have $\mathrm{O}_{2}$ changes indicating significant (at the $95 \%$ confidence level) increases in oxygen.

The average $\mathrm{O}_{2}$ change for these tests is -0.00009 moles, and the average uncertainties corresponding to the error propagation approaches of Table 5 range from a high of 0.000053 moles to a low of 0.0000094 moles. Expressed as relative uncertainties, these high and low values are $59 \%$ and $10 \%$, respectively.

Exhibit A8 in the Appendix provides a plot of the initial versus final moles of oxygen for these tests. A paired t-test for these data (assuming that these test results are representative of --- i.e., a random sample from --- the intended operational window for the 9975) is also provided in this exhibit. This statistical test reveals that the null hypothesis of a zero mean difference between the initial 
and final moles of oxygen (final - initial) for these experiments is strongly rejected (the probability of obtaining these results by chance alone is 1 in 100,000 if there is no difference in the quantity of $\mathrm{O}_{2}$ ) in favor of the hypothesis that the mean oxygen difference is less than zero; i.e., in favor of the hypothesis that on average oxygen is depleted for these tests.

\section{CONCLUSIONS}

A review of the oxygen data from the gas generation tests supporting the 9975 SARP has been conducted including the development of an error propagation of the measurement uncertainties into the equation for the change in moles of $\mathrm{O}_{2}$. This analysis revealed tests with significant (at a $95 \%$ confidence level) differences between their beginning and ending moles of $\mathrm{O}_{2}$ based upon the measurement and analytical uncertainties assumed in this report.

\section{REFERENCES}

[1] Livingston, Ronald R., Gas Generation Test Support for Revision of 9975 SARP: Task Technical and Quality Assurance Plan," WSRC-RP-99-00164, February 18, 1999.

[2] SAS Institute, JMP® Statistics and Graphics Guide, Version 3 of JMP, SAS Institute Inc., Cary, NC, 1995.

[3] Coleman, Hugh W. and W. Glenn Steele, Jr., Experimentation and Uncertainty Analysis for Engineers, John Wiley \& Sons, Inc., New York, 1989. 
WSRC-RP-99-00595

Revision 0

This page intentionally left blank. 


\section{APPENDIX:}

TABLES AND EXHIBITS 
WSRC-RP-99-00595

Revision 0

This page intentionally left blank. 
Table A1: Test Measurements by Test Number ${ }^{4}$

\begin{tabular}{|c|c|c|c|c|c|c|c|c|c|c|c|c|c|c|c|c|c|}
\hline Test & $\begin{array}{l}\text { Volume } \\
\text { (cc) }\end{array}$ & $\begin{array}{l}\text { Initial } \\
\text { Pressure } \\
\text { (torr) }\end{array}$ & $\begin{array}{c}\text { Initial } \\
\text { Temperature } \\
\left({ }^{\circ} \mathrm{K}\right)\end{array}$ & $\begin{array}{l}\text { Initial } \\
\text { Total } \\
\text { moles }\end{array}$ & $\begin{array}{c}\text { Estimate } \\
\text { Initial } \mathrm{N}_{2} \\
\text { moles }\end{array}$ & $\begin{array}{c}\text { Estimate } \\
\text { Initial } \mathrm{O}_{2} \\
\text { moles }\end{array}$ & $\begin{array}{c}\text { Final } \\
\text { Pressure } \\
\text { (torr) }\end{array}$ & $\begin{array}{c}\text { Final } \\
\text { Temperature } \\
\text { ("C) }\end{array}$ & $\begin{array}{c}\text { Final } \\
\text { Temperature } \\
\text { ("K) }\end{array}$ & $\begin{array}{l}\text { Final } \\
\text { Total } \\
\text { moles }\end{array}$ & $\% \mathrm{H}_{2}$ & $\% \mathrm{O}_{2}$ & $\% \mathrm{~N}_{2}$ & $\begin{array}{c}\text { Final } \\
\mathbf{H}_{2} \\
\text { moles }\end{array}$ & $\begin{array}{c}\text { Final } \\
\mathrm{O}_{2} \\
\text { moles }\end{array}$ & $\begin{array}{c}\text { Final } \\
\mathrm{N}_{2} \\
\text { moles }\end{array}$ & $\underset{\substack{\text { moles } \\
\text { (final-initial) }}}{\Delta \mathrm{O}_{2}}$ \\
\hline 1 & 34.11 & 752.2 & 296.6 & $1.388 \mathrm{E}-03$ & $1.084 \mathrm{E}-03$ & $2.907 \mathrm{E}-04$ & 743.2 & 22.7 & 295.7 & $1.376 \mathrm{E}-03$ & 0.55 & 18.80 & 84.00 & $7.566 \mathrm{E}-06$ & $2.586 \mathrm{E}-04$ & $1.155 \mathrm{E}-03$ & $-3.212 \mathrm{E}-05$ \\
\hline 2 & 63.86 & 741.9 & 294.7 & $2.579 \mathrm{E}-03$ & $2.014 \mathrm{E}-03$ & $5.403 \mathrm{E}-04$ & 711.8 & 24.2 & 297.2 & $2.454 \mathrm{E}-03$ & 0.00 & 17.90 & 84.50 & $0.000 \mathrm{E}+00$ & $4.393 \mathrm{E}-04$ & $2.074 \mathrm{E} \cdot 03$ & $-1.010 \mathrm{E}-04$ \\
\hline 3 & 30.50 & 740.9 & 299.3 & $1.211 \mathrm{E}-03$ & $9.459 \mathrm{E}-04$ & $2.537 \mathrm{E}-04$ & 741.3 & 22.9 & 295.9 & $1.226 \mathrm{E}-03$ & 0.00 & 21.10 & 82.30 & $0.000 \mathrm{E}+00$ & $2.587 \mathrm{E}-04$ & $1.009 \mathrm{E}-03$ & $4.942 \mathrm{E}-06$ \\
\hline 4 & 30.90 & 748.3 & 298.5 & $1.243 \mathrm{E}-03$ & $9.705 \mathrm{E}-04$ & 2.603E-04 & 751.5 & 22.4 & 295.4 & $1.261 \mathrm{E}-03$ & 0.00 & 20.10 & 82.50 & $0.000 \mathrm{E}+00$ & $2.535 \mathrm{E}-04$ & $1.041 \mathrm{E}-03$ & $-6.814 \mathrm{E}-06$ \\
\hline 5 & 29.81 & 755.5 & 297.3 & $1.215 \mathrm{E}-03$ & $9.491 \mathrm{E}-04$ & $2.546 \mathrm{E}-04$ & 891.3 & 22.5 & 295.5 & $1.443 \mathrm{E}-03$ & 10.80 & 22.80 & 61.70 & $1.558 \mathrm{E}-04$ & $3.289 \mathrm{E}-04$ & $8.901 \mathrm{E}-04$ & $7.434 \mathrm{E}-05$ \\
\hline 6 & 62.33 & 775.7 & 295.5 & $2.625 \mathrm{E}-03$ & $2.050 \mathrm{E}-03$ & 5.499E-04 & 774.7 & 21.5 & 294.5 & $2.631 \mathrm{E}-03$ & 4.20 & 3.90 & 81.60 & $1.105 \mathrm{E}-04$ & $1.026 \mathrm{E}-04$ & 2.147E-03 & $-4.473 \mathrm{E}-04$ \\
\hline 7 & 49.71 & 649.4 & 296.2 & $1.749 \mathrm{E}-03$ & $1.365 \mathrm{E}-03$ & $3.663 \mathrm{E}-04$ & 808.1 & 105.5 & 331.0 & $1.947 \mathrm{E}-03$ & 3.70 & 3.60 & 87.00 & $7.206 \mathrm{E}-05$ & $7.011 \mathrm{E}-05$ & $1.694 \mathrm{E}-03$ & $-2.962 \mathrm{E}-04$ \\
\hline 8 & 64.10 & 750.2 & 295.6 & $2.610 \mathrm{E}-03$ & $2.038 \mathrm{E}-03$ & $5.467 \mathrm{E}-04$ & 735.1 & 22.7 & 295.7 & $2.557 \mathrm{E}-03$ & 0.05 & 19.60 & 86.00 & $1.278 \mathrm{E}-06$ & $5.011 \mathrm{E}-04$ & $2.199 \mathrm{E}-03$ & $-4.560 \mathrm{E}-05$ \\
\hline 9 & 62.91 & 734.5 & 299.1 & $2.479 \mathrm{E}-03$ & $1.936 \mathrm{E}-03$ & $5.192 \mathrm{E}-04$ & 733.3 & 25.2 & 298.2 & $2,482 \mathrm{E}-03$ & 0.08 & 20.20 & 85.10 & $1.986 \mathrm{E}-06$ & $5.014 \mathrm{E}-04$ & $2.112 \mathrm{E}-03$ & $-1.780 \mathrm{E}-05$ \\
\hline 10 & 43.46 & 746.5 & 298.5 & $1.744 \mathrm{E}-03$ & $1.362 \mathrm{E}-03$ & $3.653 \mathrm{E}-04$ & 746.5 & 22.8 & 295.8 & $1.760 \mathrm{E}-03$ & 0.62 & 20.20 & 83.80 & $1.091 \mathrm{E}-05$ & 3.555E-04 & $1.475 \mathrm{E}-03$ & $-9.794 \mathrm{E}-06$ \\
\hline 11 & 38.51 & 755.7 & 296.4 & $1.575 \mathrm{E}-03$ & $1.230 \mathrm{E}-03$ & $3.300 \mathrm{E}-04$ & 749.7 & 22.9 & 295.9 & $1.566 \mathrm{E}-03$ & 0.26 & 19.70 & 88.10 & $4.070 \mathrm{E}-06$ & $3.084 \mathrm{E}-04$ & $1.379 \mathrm{E}-03$ & $-2.157 \mathrm{E}-05$ \\
\hline 12 & 30.72 & 756.6 & 297.5 & 1.254E-03 & $9.788 \mathrm{E}-04$ & $2.626 \mathrm{E}-04$ & 753.7 & 23.1 & 296.1 & $1.255 \mathrm{E}-03$ & 0.54 & 20.00 & 84.80 & $6.775 \mathrm{E}-06$ & $2.509 \mathrm{E}-04$ & $1.064 \mathrm{E}-03$ & $-1.164 \mathrm{E}-05$ \\
\hline 13 & 51.66 & 762.3 & 302.1 & $2.092 \mathrm{E}-03$ & $1.633 \mathrm{E}-03$ & 4.381E-04 & 655.9 & 22.9 & 295.9 & $1.837 \mathrm{E}-03$ & 6.19 & 3.10 & 90.80 & $1.137 \mathrm{E}-04$ & $5.696 \mathrm{E}-05$ & $1.668 \mathrm{E}-03$ & $-3.811 \mathrm{E}-04$ \\
\hline 14 & 64.37 & 765.1 & 296.3 & $2.667 \mathrm{E}-03$ & $2.082 \mathrm{E}-03$ & $5.586 \mathrm{E}-04$ & 975.2 & 97.8 & 329.5 & $3.057 \mathrm{E}-03$ & 0.89 & 16.70 & 80.00 & $2.721 \mathrm{E}-05$ & $5.105 \mathrm{E}-04$ & $2.446 \mathrm{E}-03$ & $-4.809 \mathrm{E}-05$ \\
\hline 15 & 65.63 & 754.1 & 299.6 & $2.651 \mathrm{E}-03$ & $2.070 \mathrm{E}-03$ & $5.552 \mathrm{E}-04$ & 806.3 & 111.7 & 327.6 & $2.592 \mathrm{E}-03$ & 0.00 & 11.70 & 82.60 & $0.000 \mathrm{E}+00$ & $3.032 \mathrm{E}-04$ & $2.141 \mathrm{E}-03$ & $-2.520 \mathrm{E}-04$ \\
\hline 16 & 30.78 & 760.2 & 296.1 & $1.268 \mathrm{E}-03$ & $9.901 \mathrm{E}-04$ & $2.656 \mathrm{E}-04$ & 753.2 & 109.2 & 314.3 & $1.184 \mathrm{E}-03$ & 0.22 & 15.50 & 78.20 & $2.604 \mathrm{E}-06$ & $1.835 \mathrm{E}-04$ & $9.256 \mathrm{E}-04$ & $-8.211 \mathrm{E}-05$ \\
\hline 17 & 42.04 & 762.2 & 298.0 & I.725E-03 & $1.347 \mathrm{E}-03$ & $3.614 \mathrm{E}-04$ & 779.1 & 24.2 & 297.2 & $1.768 \mathrm{E}-03$ & 1.64 & 20.60 & 79.60 & $2.900 \mathrm{E}-05$ & 3.643E-04 & $1.408 \mathrm{E}-03$ & $2.889 \mathrm{E}-06$ \\
\hline 18 & 30.34 & 760.0 & 298.0 & $1.242 \mathrm{E}-03$ & $9.694 \mathrm{E}-04$ & $2.600 \mathrm{E}-04$ & 1179.8 & 23.4 & 296.4 & $1.938 \mathrm{E}-03$ & 24.15 & 15.50 & 53.10 & $4.680 \mathrm{E}-04$ & $3.003 \mathrm{E}-04$ & $1.029 \mathrm{E}-03$ & $4.029 \mathrm{E}-05$ \\
\hline 19 & 52.40 & 751.7 & 298.4 & $2.118 \mathrm{E}-03$ & $1.654 \mathrm{E}-03$ & $4.436 \mathrm{E}-04$ & 744.5 & 24.4 & 297.4 & $2.105 \mathrm{E}-03$ & 0.00 & 18.20 & 83.80 & $0.000 \mathrm{E}+\infty 0$ & $3.831 \mathrm{E}-04$ & $1.764 \mathrm{E}-03$ & $-6.057 \mathrm{E}-05$ \\
\hline 20 & 53.82 & 753.4 & 297.6 & $2.186 \mathrm{E}-03$ & $1.707 \mathrm{E}-03$ & 4.579E-04 & 1178.3 & 25.1 & 321.3 & $3.167 \mathrm{E}-03$ & 80.00 & 0.00 & 23.60 & $2.534 \mathrm{E}-03$ & $0.000 \mathrm{E}+00$ & $7.474 \mathrm{E}-04$ & $-4.579 \mathrm{E}-04$ \\
\hline 21 & 25.98 & 744.0 & 298.4 & $1.039 \mathrm{E}-03$ & $8.115 \mathrm{E}-04$ & $2.177 \mathrm{E}-04$ & 803.2 & 94.7 & 323.0 & $1.037 \mathrm{E}-03$ & 2.60 & 6.00 & 95.60 & $2.695 \mathrm{E}-05$ & $6.220 \mathrm{E}-05$ & $9.910 \mathrm{E}-04$ & $-1.555 \mathrm{E}-04$ \\
\hline 22 & 43.03 & 749.4 & 298.3 & $1.734 \mathrm{E}-03$ & $1.354 \mathrm{E}-03$ & 3.633E-04 & 742.1 & 25 & 298.0 & $1.719 \mathrm{E}-03$ & 0.13 & 15.40 & 86.30 & $2.235 \mathrm{E}-06$ & $2.648 \mathrm{E}-04$ & $1.484 \mathrm{E}-03$ & $-9.853 \mathrm{E}-05$ \\
\hline 23 & 31.95 & 758.2 & 299.0 & $1.300 \mathrm{E}-03$ & $1.015 \mathrm{E}-03$ & $2.723 \mathrm{E}-04$ & 806.3 & 96.9 & 307.8 & $1.343 \mathrm{E}-03$ & 1.60 & 11.90 & 88.60 & $2.149 \mathrm{E}-05$ & $1.598 \mathrm{E}-04$ & $1.190 \mathrm{E}-03$ & $-1.125 \mathrm{E}-04$ \\
\hline 24 & 43.83 & 764.4 & 298.1 & $1.803 \mathrm{E}-03$ & $1.408 \mathrm{E}-03$ & $3.777 \mathrm{E}-04$ & 764.3 & 24.8 & 297.8 & $1.805 \mathrm{E}-03$ & 5.00 & 19.70 & 76.60 & $9.024 \mathrm{E}-05$ & $3.556 \mathrm{E}-04$ & $1.383 \mathrm{E}-03$ & $-2.216 \mathrm{E}-05$ \\
\hline 25 & 14.43 & 749.5 & 295.9 & $5.865 \mathrm{E}-04$ & $4.579 \mathrm{E}-04$ & $1.228 \mathrm{E}-04$ & 800.2 & 92.6 & 324.7 & $5.705 \mathrm{E}-04$ & 2.17 & 12.60 & 82.70 & $1.238 \mathrm{E}-05$ & $7.189 \mathrm{E}-05$ & $4.718 \mathrm{E}-04$ & $-5.095 \mathrm{E}-05$ \\
\hline 26 & 25.67 & 752.6 & 296.2 & $1.047 \mathrm{E}-03$ & $8.172 \mathrm{E}-04$ & $2.192 \mathrm{E}-04$ & 789.2 & 94.4 & 317.1 & $1.025 \mathrm{E}-03$ & 1.19 & 16.20 & 79.40 & $1.220 \mathrm{E} \cdot 05$ & $1.661 \mathrm{E}-04$ & $8.140 \mathrm{E}-04$ & $-5.312 \mathrm{E}-05$ \\
\hline 28 & 68.91 & 758.2 & 296.7 & $2.825 \mathrm{E}-03$ & $2.206 \mathrm{E}-03$ & $5.918 \mathrm{E}-04$ & 829.8 & 24.9 & 297.9 & $3.080 \mathrm{E}-03$ & 1.82 & 24.20 & 68.20 & $5.605 \mathrm{E}-05$ & $7.453 \mathrm{E}-04$ & $2.100 \mathrm{E}-03$ & $1.535 \mathrm{E}-04$ \\
\hline 29 & 27.47 & 768.4 & 371.7 & $9.112 \mathrm{E}-04$ & $7.115 \mathrm{E}-04$ & $1.909 \mathrm{E}-04$ & 341.5 & 99.3 & 419.5 & $3.588 \mathrm{E}-04$ & 0.46 & 13.30 & 85.80 & $1.650 \mathrm{E}-06$ & $4.772 \mathrm{E}-05$ & $3.078 \mathrm{E}-04$ & $-1.431 \mathrm{E}-04$ \\
\hline 30 & 63.26 & 755.8 & 297.8 & $2.576 \mathrm{E}-03$ & $2.011 \mathrm{E}-03$ & $5.396 \mathrm{E}-04$ & 724.6 & 24.6 & 297.6 & $2.471 E-03$ & 1.27 & 16.50 & 75.80 & $3.139 \mathrm{E}-05$ & $4.078 \mathrm{E}-04$ & $1.873 \mathrm{E}-03$ & $-1.318 \mathrm{E}-04$ \\
\hline 31 & 26.22 & 733.8 & 369.5 & $8.355 \mathrm{E}-04$ & $6.524 \mathrm{E}-04$ & $1.750 \mathrm{E}-04$ & 738.8 & 94.5 & 367.5 & $8.457 \mathrm{E}-04$ & 0.03 & 20.50 & 76.00 & $2.537 \mathrm{E}-07$ & $1.734 \mathrm{E}-04$ & $6.428 \mathrm{E}-04$ & $-1.621 \mathrm{E}-06$ \\
\hline 32 & 91.65 & 753.9 & 297.5 & $3.726 \mathrm{E}-03$ & $2.910 \mathrm{E}-03$ & $7.805 \mathrm{E}-04$ & 772.2 & 23.9 & 296.9 & $3.825 \mathrm{E}-03$ & 8.13 & 12.90 & 78.50 & $3.109 \mathrm{E}-04$ & $4.934 \mathrm{E}-04$ & $3.002 \mathrm{E}-03$ & $-2.872 \mathrm{E}-04$ \\
\hline 33 & 38.54 & 760.0 & 298.8 & $1.573 \mathrm{E}-03$ & $1.228 \mathrm{E}-03$ & $3.294 \mathrm{E}-04$ & 751.8 & 23.8 & 296.8 & $1.566 \mathrm{E}-03$ & 1.60 & 20.20 & 76.40 & $2.506 \mathrm{E}-05$ & $3.164 \mathrm{E}-04$ & $1.197 \mathrm{E}-03$ & $-1.304 \mathrm{E}-05$ \\
\hline 34 & 38.98 & 768.9 & 298.9 & $1.609 \mathrm{E}-03$ & $1.256 \mathrm{E}-03$ & 3.370E-04 & 760.5 & 23.9 & 296.9 & $1.602 \mathrm{E}-03$ & 0.20 & 20.20 & 76.90 & $3.204 \mathrm{E}-06$ & $3.236 \mathrm{E}-04$ & $1.232 \mathrm{E}-03$ & $-1.339 \mathrm{E}-05$ \\
\hline 35 & 53.04 & 745.8 & 296.4 & $2.141 \mathrm{E}-03$ & $1.672 \mathrm{E}-03$ & $4.485 \mathrm{E}-04$ & 755.3 & 24.4 & 297.4 & $2.161 \mathrm{E}-03$ & 0.00 & 18.90 & 55.20 & $0.000 \mathrm{E}+00$ & $4.085 \mathrm{E}-04$ & $1.193 \mathrm{E}-03$ & $.4 .003 \mathrm{E}-05$ \\
\hline 36 & 61.32 & 748.5 & 297.9 & $2.472 \mathrm{E}-03$ & $1.930 \mathrm{E}-03$ & $5.178 \mathrm{E}-04$ & 3843.2 & 106.3 & 324.5 & $1.165 \mathrm{E}-02$ & 74.70 & 1.30 & 17.90 & $8.703 \mathrm{E}-03$ & $1.515 \mathrm{E}-04$ & $2.086 \mathrm{E}-03$ & $-3.663 \mathrm{E}-04$ \\
\hline 37 & 26.49 & 741.6 & 297.4 & $1.060 \mathrm{E}-03$ & $8.276 \mathrm{E}-04$ & $2.220 \mathrm{E}-04$ & 813.1 & 106.1 & 316.1 & $1.093 \mathrm{E}-03$ & 0.40 & 20.00 & 64.20 & $4.373 \mathrm{E}-06$ & $2.187 \mathrm{E}-04$ & 7.019E-04 & $-3.334 \mathrm{E}-06$ \\
\hline 38 & 44.90 & 744.9 & 297.4 & $1.804 \mathrm{E}-03$ & $1.409 \mathrm{E}-03$ & $3.780 \mathrm{E}-04$ & 802.2 & 24.9 & 297.9 & $1.940 \mathrm{E}-03$ & 7.40 & 14.10 & 77.70 & $1.436 \mathrm{E}-04$ & $2.735 \mathrm{E}-04$ & $1.507 \mathrm{E}-03$ & $-1.044 \mathrm{E}-04$ \\
\hline 39 & 46.04 & 752.4 & 297.4 & $1.869 \mathrm{E}-03$ & $1.459 \mathrm{E}-03$ & $3.915 \mathrm{E}-04$ & 758.3 & 24.8 & 297.8 & $1.881 \mathrm{E}-03$ & 6.50 & 20.80 & 72.10 & $1.223 \mathrm{E}-04$ & $3.913 \mathrm{E}-04$ & $1.356 \mathrm{E}-03$ & $-2.066 \mathrm{E}-07$ \\
\hline 40 & 46.27 & 759.7 & 297.9 & $1.893 \mathrm{E}-03$ & $1.478 \mathrm{E}-03$ & 3. $966 \mathrm{E}-04$ & 805.8 & 25.0 & 298.0 & $2.007 \mathrm{E}-03$ & 3.00 & 20.10 & 54.40 & $6.022 \mathrm{E}-05$ & $4.035 \mathrm{E}-04$ & $1.092 \mathrm{E}-03$ & $6.940 \mathrm{E}-06$ \\
\hline 41 & 19.25 & 750.0 & 298.2 & $7.769 \mathrm{E}-04$ & $6.066 \mathrm{E}-04$ & $1.627 \mathrm{E}-04$ & 742.32 & 23.4 & 296.4 & $7.736 \mathrm{E}-04$ & 0.70 & 19.90 & 81.20 & $5.415 \mathrm{E}-06$ & $1.539 \mathrm{E}-04$ & $6.282 \mathrm{E}-04$ & $-8.780 \mathrm{E}-06$ \\
\hline 42 & 72.90 & 751,6 & 301.3 & $2.918 \mathrm{E}-03$ & $2.278 \mathrm{E}-03$ & $6.112 \mathrm{E}-04$ & 739.1 & 23.9 & 296.9 & $2.912 \mathrm{E}-03$ & 0.10 & 19.70 & 80.00 & $2.912 \mathrm{E}-06$ & $5.736 \mathrm{E}-04$ & $2.330 \mathrm{E}-03$ & $-3.754 \mathrm{E}-05$ \\
\hline 43 & 70.24 & 742.4 & 303.0 & $2.761 \mathrm{E}-03$ & $2.156 \mathrm{E}-03$ & 5.784E-04 & 730.8 & 23.9 & 296.9 & $2.774 \mathrm{E}-03$ & 0.00 & 20.90 & 79.50 & $0.000 \mathrm{E}+00$ & $5.798 \mathrm{E}-04$ & 2.205E-03 & $1.384 \mathrm{E}-06$ \\
\hline 44 & 123.67 & 750.5 & 300.6 & $4.954 \mathrm{E}-03$ & $3.868 \mathrm{E}-03$ & $1.038 \mathrm{E}-03$ & 722.7 & 24. & 297.4 & $4.822 \mathrm{E}-03$ & 0.20 & 18.60 & 82.40 & $9.644 \mathrm{E}-06$ & $8.969 \mathrm{E}-04$ & $3.973 \mathrm{E}-03$ & $-1.408 \mathrm{E}-04$ \\
\hline 45 & 37.51 & 756.9 & 298.5 & $1.526 \mathrm{E}-03$ & 1.192E-03 & $3.196 \mathrm{E}-04$ & 782.5 & 24.4 & 297.4 & $1.583 \mathrm{E}-03$ & 2.30 & 21.00 & 76.80 & 3.642E-05 & $3.325 \mathrm{E}-04$ & $1.216 \mathrm{E}-03$ & $1.289 \mathrm{E}-05$ \\
\hline
\end{tabular}

Test 27 was unsuccessful due to equipment failure. 
Table A1: Test Measurements by Test Number (continued)

\begin{tabular}{|c|c|c|c|c|c|c|c|c|c|c|c|c|c|c|c|c|c|}
\hline Test & $\begin{array}{l}\text { Volume } \\
\text { (cc) }\end{array}$ & $\begin{array}{l}\text { Initial } \\
\text { Pressure } \\
\text { (torr) }\end{array}$ & $\begin{array}{c}\text { Initial } \\
\text { Temperature } \\
\left({ }^{\circ} \mathrm{K}\right)\end{array}$ & $\begin{array}{l}\text { Initial } \\
\text { Total } \\
\text { moles }\end{array}$ & $\begin{array}{c}\text { Estimate } \\
\text { Initial } \mathrm{N}_{2} \\
\text { moles }\end{array}$ & $\begin{array}{c}\text { Estimate } \\
\text { Initial } \mathrm{O}_{2} \\
\text { moles }\end{array}$ & $\begin{array}{l}\text { Final } \\
\text { Pressure } \\
\text { (torr) }\end{array}$ & $\begin{array}{c}\text { Final } \\
\text { Temperature } \\
\text { ("C) }\end{array}$ & $\begin{array}{c}\text { Final } \\
\text { Temperature } \\
\text { ('K) }\end{array}$ & $\begin{array}{l}\text { Final } \\
\text { Total } \\
\text { moles }\end{array}$ & $\% \mathrm{H}_{2}$ & $\% \mathrm{O}_{2}$ & $\% \mathrm{~N}_{2}$ & $\begin{array}{c}\text { Final } \\
\mathrm{H}_{2} \\
\text { moles }\end{array}$ & $\begin{array}{c}\text { Final } \\
\mathrm{O}_{2} \\
\text { moles }\end{array}$ & $\begin{array}{c}\text { Final } \\
\mathrm{N}_{2} \\
\text { moles }\end{array}$ & $\underset{\substack{\text { moles } \\
\text { (final-initial) }}}{\Delta \mathrm{O}_{2}}$ \\
\hline 46 & 38.12 & 763.9 & 298.9 & $1.563 \mathrm{E}-03$ & $1.221 \mathrm{E}-03$ & $3.274 \mathrm{E}-04$ & 788.3 & 23.9 & 296.9 & $1.624 \mathrm{E}-03$ & 1.20 & 21.10 & 62.10 & $1.949 \mathrm{E}-05$ & $3.427 \mathrm{E}-04$ & $1.009 \mathrm{E}-03$ & $1.524 \mathrm{E}-05$ \\
\hline 47 & 18.96 & 749.7 & 297.9 & 7.654E-04 & 5.977E-04 & $1.603 \mathrm{E}-04$ & 1197.3 & 97 & 370.0 & $9.842 \mathrm{E}-04$ & 3.40 & 7.30 & 81.80 & $3.346 \mathrm{E}-05$ & $7.185 \mathrm{E}-05$ & $8.051 \mathrm{E}-04$ & $-8.847 \mathrm{E}-05$ \\
\hline 48 & 71.59 & 752.4 & 297.7 & $.903 \mathrm{E}-03$ & $2.267 \mathrm{E}-03$ & $6.081 \mathrm{E}-04$ & 1095.2 & 63.7 & 336.7 & $3.736 \mathrm{E}-03$ & 0.00 & 22.70 & 74.00 & $0.000 \mathrm{E}+00$ & $8.480 \mathrm{E}-04$ & $.765 \mathrm{E}-03$ & $2.399 \mathrm{E}-04$ \\
\hline 49 & 69.90 & 744.4 & 297.8 & $2.804 \mathrm{E}-03$ & $2.189 \mathrm{E}-03$ & $5.872 \mathrm{E}-04$ & 1092.7 & 60.9 & 333.9 & $3.670 \mathrm{E}-03$ & 1.50 & 29.70 & 66.40 & $5.506 \mathrm{E}-05$ & $1.090 \mathrm{E}-03$ & $2.437 \mathrm{E}-03$ & $5.029 \mathrm{E}-04$ \\
\hline 50 & 122.76 & 748.8 & 298.2 & $4.946 \mathrm{E}-03$ & 3.862E-03 & $1.036 \mathrm{E}-03$ & 736 & 25.4 & 298.4 & $4.858 \mathrm{E}-03$ & 0.40 & 18.90 & 79.20 & 1.943 & $9.182 E-04$ & 3.8 & $-1.178 \mathrm{E}-04$ \\
\hline 51 & 18.74 & 755.7 & 298.1 & $7.623 \mathrm{E}-04$ & 5.95 & & 75 & & & & 1.50 & 19.90 & 73.40 & & & -04 & $-8.435 \mathrm{E}-06$ \\
\hline 52 & 45.1 & 762.5 & 2 & $1.848 \mathrm{E}-03$ & 1.44 & 3.87 & 747 & 25 & 29 & $1.815 \mathrm{E}-03$ & 0.5 & 20.14 & 78.36 & 9.9 & -04 & 1.4 & $-2.154 \mathrm{E}-05$ \\
\hline 53 & 18.74 & 75 & 2 & $7.627 \mathrm{E}-04$ & 5.95 & & 872 & & & & 1. & 13.00 & 85.00 & & -04 & & $-5.891 \mathrm{E}-05$ \\
\hline 54 & 31.56 & 75 & & 1.282 & & 2.68 & 775 & 42.6 & 315.6 & $1.244 \mathrm{E}-03$ & 0.00 & 20.00 & 74.00 & $E+\infty$ & $8-04$ & 9.2 & $-1.977 \mathrm{E}-05$ \\
\hline 55 & 71.49 & 743.3 & 298.4 & $2.857 \mathrm{E}-03$ & 2.23 & 5.98 & 744 & 25 & & 3 & 0. & 19.00 & 84 & & & & $-5.389 \mathrm{E}-05$ \\
\hline 56 & 37.50 & 759.8 & & 532E-03 & 1.196 & $3.209 \mathrm{E}-04$ & 774.6 & 24.5 & 297.5 & $1.567 \mathrm{E}-03$ & 0.2 & 20.00 & 84.00 & -06 & 3.13 & $1.316 \mathrm{E}-03$ & $-7.580 \mathrm{E}-06$ \\
\hline 57 & 18.49 & 774,9 & 8.3 & $7.707 \mathrm{E}-04$ & $6.018 \mathrm{E}-04$ & $1.614 \mathrm{E}-04$ & 1048.9 & 27 & & & 1. & 10.10 & & 1.8 & $1.046 \mathrm{E}-04$ & $8.437 \mathrm{E}-04$ & $-5.687 \mathrm{E}-05$ \\
\hline 58 & & 750 & & $1.259 \mathrm{E}-03$ & & $2.64 \mathrm{E}-04$ & 75 & 2 & 299 & & 0 & 20 & 78 & +00 & 2.5 & & \\
\hline 59 & 59.55 & 742.4 & 298.2 & $2.379 \mathrm{E}-03$ & $1.857 \mathrm{E}-03$ & $4.983 \mathrm{E}-04$ & 1019 & 49.6 & 322.6 & $3.018 \mathrm{E}-03$ & 0.70 & 16.20 & 81.60 & $2.113 \mathrm{E}-05$ & $4.890 \mathrm{E}-04$ & $2.463 \mathrm{E}-0$ & -9.28 \\
\hline
\end{tabular}


Table A2: Description of 9975 Test by Test Number ${ }^{5}$

\begin{tabular}{|c|c|c|c|c|c|c|c|c|c|c|c|c|c|c|c|c|}
\hline $\begin{array}{c}\text { Run } \\
\#\end{array}$ & $\begin{array}{c}\text { Description } \\
\text { 2/20/99 Start -- Set } 1 \\
\end{array}$ & $\begin{array}{l}\text { Time } \\
\text { (days) }\end{array}$ & $\begin{array}{c}\text { Container } \\
\text { Volume }\end{array}$ & $\begin{array}{c}\text { Grams } \\
\mathrm{PuO}_{2} \\
\end{array}$ & $\begin{array}{c}\text { Bulk } \\
\text { Weight(g) }\end{array}$ & $\begin{array}{c}\text { Measured } \\
\text { Volume } \\
\end{array}$ & $\begin{array}{l}\text { Temp } \\
\left({ }^{\circ} \mathrm{C}\right) \\
\end{array}$ & $\begin{array}{c}\text { Run } \\
\#\end{array}$ & $\begin{array}{c}\text { Sample \# } \\
\text { 2/20/99 Start -- Set } 1 \\
\end{array}$ & $\begin{array}{c}\begin{array}{c}\mathrm{H}_{2} \\
(\mathrm{vol} \%)\end{array} \\
\end{array}$ & $\begin{array}{c}\mathrm{O}_{2} \\
(\mathrm{vol} \%) \\
\end{array}$ & $\begin{array}{c}\mathrm{N}_{2} \\
(\mathrm{vol} \%)\end{array}$ & $\begin{array}{c}\mathrm{CO}_{2} \\
(\mathrm{vol} \%)\end{array}$ & $\begin{array}{c}\mathrm{N}_{2} \mathrm{O} \\
(\mathrm{vol} \%)\end{array}$ & $\begin{array}{c}\mathrm{CO} \\
(\mathrm{vol} \%) \\
\end{array}$ & $\begin{array}{c}\text { sum } \\
\text { (vol\%) }\end{array}$ \\
\hline 1 & PuO2+ RF MgO sand \& crucible & 8.83 & $25 \mathrm{cc}$ & 9.59 & 37.83 & 34.11 & ambient & 1 & 3-123637 & 0.55 & 18.8 & 84 & 0 & 0 & $\overline{0}$ & 103.35 \\
\hline 2 & $\mathrm{PuO} 2+$ calcined $\mathrm{CaO}+\mathrm{Ca}(\mathrm{OH}) 2$ & 8.92 & $50 \mathrm{cc}$ & 8.85 & 35.80 & 63.86 & ambient & 2 & 3-123636 & 0.00 & 17.9 & 84.5 & 0 & 0 & 0 & 102.40 \\
\hline 3 & PuO2 Stored over dessicant & 9.65 & $5 c c$ & 7.65 & 7.65 & 30.50 & ambient & 3 & 3-123635 & 0.00 & 21.1 & 82.3 & 0.05 & 0 & 0 & 103.45 \\
\hline 4 & PuO2 stored in $76 \%$ RH humidor & 9.71 & $5 \mathrm{cc}$ & 8.54 & 8.54 & 30.90 & ambient & 4 & 3.123634 & 0.00 & 20.1 & 82.5 & 0.16 & 0 & 0 & 102.76 \\
\hline 5 & $\mathrm{PuO} 2 \sim 10 \% \mathrm{H} 2 \mathrm{O}$ added & 6.66 & $5 \mathrm{cc}$ & 7.57 & 7.57 & 29.81 & ambient & 5 & 3-123633 & 10.80 & 22.8 & 61.7 & 0.1 & 0 & 0 & 95.40 \\
\hline 6 & $\begin{array}{l}\text { Standard Gas } \\
\quad \text { 3/1/99 Start -- Set } 2\end{array}$ & 3.73 & $50 \mathrm{cc}$ & 0.00 & 0.00 & 62.33 & ambient & 6 & $\begin{array}{c}\text { 3-123638 } \\
\text { 3/1/99 Start -. Set } 2\end{array}$ & 4.20 & 3.9 & 81.6 & 1.8 & 0.5 & 1.2 & $\begin{array}{c}93.20 \\
93.20 \\
0.00\end{array}$ \\
\hline 7 & Standard Gas + Heat & 6.31 & $50 \mathrm{cc}$ & 0.00 & 0.00 & 49.71 & 90 & 7 & $3-123639$ & 3.70 & 3.6 & 87 & NR & $\mathrm{NR}$ & 4.06 & 98.36 \\
\hline 8 & $\# 2$ stored at $100 \% \mathrm{RH}$ & 6.14 & $50 \mathrm{cc}$ & 7.73 & 31.30 & 64.10 & ambient & 8 & $3-123640$ & 0.05 & 19.6 & 86 & 0.1 & 0 & 0 & 105.75 \\
\hline 9 & $\mathrm{PuO} 2+30 \mathrm{~g} \mathrm{CaF} 2$ & 6.83 & $50 \mathrm{cc}$ & 9.83 & 39.85 & 62.91 & ambient & 9 & 3-123641 & 0.08 & 20.2 & 85.1 & 0.09 & 0.02 & 0 & 105.49 \\
\hline 10 & $\mathrm{PuO} 2+\mathrm{Ca}(\mathrm{OH}) 2 \& \mathrm{MgO}$ Crucible & 5.75 & $25 \mathrm{cc}$ & 7.90 & 15.80 & 43.46 & ambient & 10 & $3-123642$ & 0.62 & 20.2 & 83.8 & 0.06 & 0 & 0 & 104.68 \\
\hline 11 & $\# 1$ stored at $100 \% \mathrm{RH}$ & 6.12 & $25 \mathrm{cc}$ & 9.32 & 36.76 & 38.51 & ambient & 11 & 3-123643 & 0.26 & 19.7 & 88.1 & 0.05 & 0.04 & 4.28 & 112.43 \\
\hline 12 & $\begin{array}{c}\text { PuO2 stored at } 100 \% \text { RH } \\
\text { 3/8/99 Start - Set } 3 \\
\end{array}$ & 6.82 & $5 c c$ & 9.52 & 9.52 & 30.72 & ambient & 12 & $\begin{array}{c}3-123644 \\
3 / 8 / 99 \text { Start -. Set } 3 \\
\end{array}$ & 0.54 & 20 & 84.8 & 0.12 & 0.12 & 0 & 105.58 \\
\hline 13 & $44 \mathrm{~g}$ of RF SS\&C sample $\mathrm{H} 6$ & 7.88 & $50 \mathrm{cc}$ & 15.50 & 43.84 & 51.66 & ambient & 13 & $3-123645$ & 6.19 & 3.1 & 90.8 & 0.03 & 1.6 & $\overline{0}$ & 101.72 \\
\hline 14 & \#9 heated & 7.88 & $50 \mathrm{cc}$ & 9,83 & 39.85 & 64.37 & 90 & 14 & 3.123646 & 0.89 & 16.7 & 80 & 5.2 & 0.25 & 0 & 103.04 \\
\hline 15 & $\# 8$ heated & 8.16 & $50 \mathrm{cc}$ & 7.73 & 31.30 & 65.63 & 90 & 15 & 3-123647 & 0.00 & 11.7 & 82.6 & 0 & 0 & 0 & 94.30 \\
\hline 16 & PuO2 stored at $100 \% \mathrm{RH}+$ Heat & 7.77 & $5 \mathrm{cc}$ & 7.26 & 7.26 & 30.78 & 90 & 16 & 3-123648 & 0.22 & 15.5 & 78.2 & 0.48 & 0.04 & 0 & 94.44 \\
\hline 17 & Pu Cake (no added moisture) & 7.61 & $25 \mathrm{cc}$ & 32.01 & 35.66 & 42.04 & ambient & 17 & 3-123649 & 1.64 & 20.6 & 79.6 & 0.06 & 0.05 & 0 & 101.95 \\
\hline 18 & $\begin{array}{r}\# 5 \text { mixed with } 2 \mathrm{~g} \text { Ca metal } \\
3 / 17 / 99 \text { Start-- Set } 4 \\
\end{array}$ & 7.56 & $5 c c$ & 4.88 & 6.93 & 30.34 & ambient & 18 & $\begin{array}{c}\text { 3-123650 } \\
\text { 3/17/99 Start-- Set 4 }\end{array}$ & 24.15 & 15.5 & 53.1 & 0.03 & 0 & 0 & $\begin{array}{c}92.78 \\
0.00 \\
\end{array}$ \\
\hline 19 & $\mathrm{CaF} 2$ at $\mathrm{RT}$ repeat $\# 14$ and $\# 9$ & 6.8 & $50 \mathrm{cc}$ & 9.83 & 39.85 & 52.40 & ambient & 19 & $3-123651$ & 0.00 & 18.2 & 83.8 & 0.37 & 0.08 & 0 & 102.45 \\
\hline 20 & $\# 13$ heated & 6.8 & $50 \mathrm{cc}$ & 15.50 & 43.84 & 53.82 & 90 & 20 & 3-123652 & 80.00 & 0 & 23.6 & 0 & 0 & 0 & 103.60 \\
\hline 21 & $\# 10$ heated & 6.81 & $10 \mathrm{cc}$ & 7.50 & 15.00 & 25.98 & 90 & 21 & 3.123653 & 2.60 & 6 & 95.6 & 0.16 & 0.2 & 0 & 104.56 \\
\hline 22 & $\mathrm{PuO2}+\mathrm{MgO}$ 1:1 ratio & 6.81 & $25 \mathrm{cc}$ & 9.73 & 19.45 & 43.03 & ambient & 22 & 3-123654 & 0.13 & 15.4 & 86.3 & 0.09 & 0.11 & 0 & 102,03 \\
\hline 23 & $\# 11$ heated & 6.78 & $10 \mathrm{cc}$ & 4.66 & 20.00 & 31.95 & 90 & 23 & 3-123655 & 1.60 & 11.9 & 88.6 & 0.22 & 0.17 & 0 & 102.49 \\
\hline 24 & $\mathrm{PuO} 2+\underset{3 / 26 / 99}{\mathrm{Mg}}$ Start-- Set 5 & 6.79 & $25 \mathrm{cc}$ & 7.26 & 17.26 & 43.83 & ambient & 24 & $\begin{array}{c}\text { 3-123656 } \\
\text { 3/26/99 Start-- Set } 5\end{array}$ & 5.00 & 19.7 & 76.6 & 0.03 & 0.09 & 0 & $\begin{array}{c}101.42 \\
0.00\end{array}$ \\
\hline 25 & $\mathrm{PuO} 2+\mathrm{MgO}$ with lo water & 10.11 & $10 \mathrm{cc}$ & 6.60 & 25.00 & 14.43 & 90 & 25 & $3-123658$ & 2.17 & 12.6 & 82.7 & $<.1$ & $<.1$ & $<.1$ & 9.00 \\
\hline 26 & $\begin{array}{r}\text { PuO2+ MgO with med water } \\
4 / 6 / 99 \text { Start-- Set } 6 \\
\end{array}$ & 9.74 & $10 \mathrm{cc}$ & 6.24 & 23.43 & 25.67 & 90 & 26 & $\begin{array}{c}\text { 3-123659 } \\
\text { 4/6/99 Start-- Set } 6 \\
\end{array}$ & 1.19 & 16.2 & 79.4 & $<.1$ & $<.1$ & $<1$ & 96.79 \\
\hline 30 & RFETS H2 & 7.69 & $50 \mathrm{cc}$ & 8.18 & 43.10 & 63,26 & ambient & 30 & $3-125514$ & 1.27 & 16.5 & 75.8 & $<.1$ & $<<.1$ & $<<1$ & 93.57 \\
\hline 31 & $\mathrm{PuO} 2+\mathrm{MgO} w /$ hi watertheat & 8.83 & $10 \mathrm{cc}$ & \#REF! & 23.09 & 26.22 & $90 \mathrm{C}$ & 31 & 3-125515 & 0.03 & 20.5 & 76 & $<.1$ & $<1$ & $<.1$ & 96.53 \\
\hline 32 & RFETS H7 & 7.71 & $100 \mathrm{cc}$ & 6.77 & 14.60 & 91.65 & ambient & 32 & 3-125516 & 8.13 & 12.9 & 78.5 & $<.1$ & $<.1$ & $<.1$ & 99.53 \\
\hline 33 & $\# 18$ repeated & 7.71 & $10 \mathrm{cc}$ & 4.65 & 6.60 & 38.54 & ambient & 33 & 3-125517 & 1.6 & 20.2 & 76.4 & $<.1$ & $<.1$ & $<.1$ & 98.20 \\
\hline 34 & $\begin{array}{l}\text { RFETS H8 } \\
\quad 4 / 16 / 99 \text { Start --Set } 7 \\
\end{array}$ & 7.69 & $10 c c$ & 8.49 & 10.80 & 38.98 & ambient & 34 & $\begin{array}{c}\text { 3-125518 } \\
\text { 4/16/99 Start - - Set } 7 \\
\end{array}$ & 0.2 & 20.2 & 76.9 & $<.1$ & $<.1$ & $<.1$ & 97.30 \\
\hline 36 & RFETS Sample H2 & 5.61 & $50 \mathrm{cc}$ & 8.18 & 43.10 & 61.32 & 90 & 36 & $3-125520$ & 74.70 & 1.3 & 17.9 & 0.02 & $<.1$ & $<.1$ & 93.92 \\
\hline 37 & $\# 31$ repeated & 5.66 & $10 \mathrm{cc}$ & 6.15 & 23.09 & 26.49 & 90 & 37 & $3-125521$ & 0.40 & 20 & 64.2 & 0.03 & 0.02 & $<.1$ & 84.65 \\
\hline 38 & $\begin{array}{l}\mathrm{PuO} 2+5 \% \mathrm{H} 2 \mathrm{O} \\
4 / 23 / 99 \text { Start } \ldots \text { Set } 8\end{array}$ & 5.69 & $25 \mathrm{cc}$ & 9.66 & 10.29 & 44.90 & ambient & 38 & $\begin{array}{c}3-125522 \\
4 / 23 / 99 \text { Start -. Set } 8\end{array}$ & 7.40 & 14.1 & 77.7 & 0.08 & 0.04 & $<.1$ & 99.32 \\
\hline 41 & PuO2+100\%RH -2weeks & 5.6 & $10 \mathrm{cc}$ & 10.08 & 10.08 & 19.25 & ambient & $\overline{4 l}$ & $3-125525$ & 0.7 & 19.9 & 81.2 & $\overline{N R}$ & NR & $<0.1$ & 101.80 \\
\hline 44 & PuCake - no treatment like \#17 & 5.77 & $100 \mathrm{cc}$ & 27.65 & 30.80 & 123.67 & ambient & 44 & $3-125528$ & 0.2 & 18.6 & 82.4 & 0.32 & $<0.1$ & $<0.1$ & 101.52 \\
\hline 45 & $\mathrm{PuO} 2+2.5 \%$ water & 5.77 & $10 \mathrm{cc}$ & 12.17 & 12.50 & 37.51 & ambient & 45 & $3-125529$ & 2.3 & 21 & 76.8 & $<0.1$ & $<0.1$ & $<0.1$ & 100.10 \\
\hline 46 & $\mathrm{PuO} 2+2.5 \%$ water & 5.84 & $10 \mathrm{cc}$ & 9.83 & 10.32 & 38.12 & ambient & 46 & $3-125530$ & 1.2 & 21.1 & 62.1 & $<0.1$ & $<0.1$ & $<0.1$ & 84.40 \\
\hline
\end{tabular}

Samples $28,29,35,40,42,43,48$ and 49 contained materials that do not conform to the content description of SS\&C residues. 
Table A2: Descriptions of Tests by Test Number (continued)

\begin{tabular}{|c|c|c|c|c|c|c|c|c|c|c|c|c|c|c|c|c|}
\hline $\begin{array}{c}\text { Run } \\
\#\end{array}$ & $\begin{array}{c}\text { Description } \\
4 / 29 / 99 \text { Start -. Set } 9 \\
\end{array}$ & $\begin{array}{c}\text { Time } \\
\text { (days) }\end{array}$ & $\begin{array}{c}\text { Container } \\
\text { Volume }\end{array}$ & $\begin{array}{c}\text { Grams } \\
\mathrm{PuO}_{2}\end{array}$ & $\begin{array}{c}\text { Bulk } \\
\text { Weight(g) }\end{array}$ & $\begin{array}{c}\text { Measured } \\
\text { Volume }\end{array}$ & $\begin{array}{c}\text { Temp } \\
\left({ }^{\circ} \mathrm{C}\right)\end{array}$ & $\begin{array}{c}\text { Run } \\
\#\end{array}$ & $\begin{array}{c}\text { Sample \# } \\
\text { 4/29/99 Start -- Set } 9 \\
\end{array}$ & $\begin{array}{c}\mathrm{H}_{2} \\
\text { (vol\%) }\end{array}$ & $\begin{array}{c}\mathrm{O}_{2} \\
(\mathrm{vol} \%)\end{array}$ & $\begin{array}{c}\mathrm{N}_{2} \\
(\mathrm{vol} \%)\end{array}$ & $\begin{array}{c}\mathrm{CO}_{2} \\
(\mathrm{vol} \%)\end{array}$ & $\begin{array}{c}\mathrm{N}_{2} \mathrm{O} \\
(\mathrm{vol} \%)\end{array}$ & $\begin{array}{c}\mathrm{CO} \\
(\mathrm{vol} \%)\end{array}$ & $\begin{array}{c}\text { sum } \\
\text { (vol\%) }\end{array}$ \\
\hline $\begin{array}{l}47 \\
50 \\
51 \\
52\end{array}$ & $\begin{array}{l}\text { PuO2+2.5\%H2O+Heat } \\
\text { PuCake - replicate } 1 \\
\text { \#41 repeated } \\
\text { PuCake - replicate } \# 2 \\
\quad \text { 5/18/99 Start -. Set } 10 \\
\end{array}$ & $\begin{array}{l}6.77 \\
6.76 \\
6.76 \\
6.77\end{array}$ & $\begin{array}{c}10 \mathrm{cc} \\
100 \mathrm{cc} \\
10 \mathrm{cc} \\
25 \mathrm{cc}\end{array}$ & $\begin{array}{l}12.17 \\
27.34 \\
10.08 \\
14.98\end{array}$ & $\begin{array}{l}12.50 \\
30.46 \\
10.08 \\
16.69\end{array}$ & $\begin{array}{c}18.96 \\
122.76 \\
37.11 \\
45.15\end{array}$ & $\begin{array}{c}90 \\
\text { ambient } \\
\text { ambient } \\
\text { ambient }\end{array}$ & $\begin{array}{l}47 \\
50 \\
51 \\
52\end{array}$ & $\begin{array}{c}3-125531 \\
3-125534 \\
3-125535 \\
3-125536 \\
\text { 5/18/99 Start } \cdots \text { Set 10 }\end{array}$ & $\begin{array}{l}3.4 \\
0.4 \\
1.5 \\
0.55\end{array}$ & $\begin{array}{c}7.3 \\
18.9 \\
19.9 \\
20.14\end{array}$ & $\begin{array}{l}81.8 \\
79.2 \\
73.4 \\
78.36\end{array}$ & $\begin{array}{l}<0.1 \\
<0.1 \\
<0.1 \\
<0.1\end{array}$ & $\begin{array}{l}<0.1 \\
<0.1 \\
<0.1 \\
0.05\end{array}$ & $\begin{array}{l}<0.1 \\
<0.1 \\
<0.1 \\
<0.1\end{array}$ & $\begin{array}{l}92.50 \\
98.50 \\
94.80 \\
99.10\end{array}$ \\
\hline $\begin{array}{l}53 \\
54 \\
55 \\
56\end{array}$ & $\begin{array}{l}\text { \#51 heated } \\
\text { Blank+Heat } \\
\text { PuO2+13mg H2O } \\
\text { PuO2+15mg H2O } \\
\quad \text { 5/26/99 Start -- Set 11 } \\
\end{array}$ & $\begin{array}{l}7.95 \\
7.95 \\
7.95 \\
7.95\end{array}$ & $\begin{array}{l}10 \mathrm{cc} \\
10 \mathrm{cc} \\
50 \mathrm{cc} \\
10 \mathrm{cc}\end{array}$ & $\begin{array}{c}10.08 \\
0.00 \\
12.57 \\
10.42\end{array}$ & $\begin{array}{c}10.08 \\
0.00 \\
12.70 \\
10.57\end{array}$ & $\begin{array}{l}18.74 \\
31.56 \\
71.49 \\
37.50\end{array}$ & $\begin{array}{c}90 \\
90 \\
\text { ambient } \\
\text { ambient }\end{array}$ & $\begin{array}{l}53 \\
54 \\
55 \\
56\end{array}$ & $\begin{array}{c}3-127169 \\
3-127170 \\
3-127171 \\
3-127172 \\
5 / 26 / 99 \text { Start - - Set 11 } \\
\end{array}$ & $\begin{array}{c}1.32 \\
0 \\
0.36 \\
0.25\end{array}$ & $\begin{array}{l}13 \\
20 \\
19 \\
20\end{array}$ & $\begin{array}{l}85 \\
74 \\
84 \\
84\end{array}$ & $\begin{array}{l}<0.1 \\
<0.1 \\
<0.1 \\
<0.1\end{array}$ & $\begin{array}{l}<0.1 \\
<0.1 \\
<0.1 \\
<0.1\end{array}$ & $\begin{array}{l}<0.1 \\
<0.1 \\
<0.1 \\
<0.1\end{array}$ & $\begin{array}{c}99.32 \\
94.00 \\
103.36 \\
104.25\end{array}$ \\
\hline $\begin{array}{l}57 \\
58 \\
59\end{array}$ & $\begin{array}{l}\text { PuO2+15mg H2O } \\
\text { Blank } \\
\text { PuO2+13mg H2O }\end{array}$ & $\begin{array}{c}7.75 \\
8 \\
7.78\end{array}$ & $\begin{array}{l}10 \mathrm{cc} \\
10 \mathrm{cc} \\
50 \mathrm{cc}\end{array}$ & $\begin{array}{l}10.42 \\
0.00 \\
12.57\end{array}$ & $\begin{array}{c}10.57 \\
0.00 \\
12.70\end{array}$ & $\begin{array}{l}18.49 \\
31.27 \\
59.55\end{array}$ & $\begin{array}{c}90 \\
\text { ambient } \\
90\end{array}$ & $\begin{array}{l}57 \\
58 \\
59\end{array}$ & $\begin{array}{l}3-127173 \\
3-127174 \\
3-127175\end{array}$ & $\begin{array}{c}1.8 \\
0 \\
0.7\end{array}$ & $\begin{array}{l}10.1 \\
20.5 \\
16.2\end{array}$ & $\begin{array}{l}81.5 \\
78.1 \\
81.6\end{array}$ & $\begin{array}{l}<0.1 \\
<0.1 \\
2.8\end{array}$ & $\begin{array}{l}<0.1 \\
<0.1 \\
0.31\end{array}$ & $\begin{array}{l}<0.1 \\
<0.1 \\
<0.1\end{array}$ & $\begin{array}{c}93.40 \\
98.60 \\
101.61\end{array}$ \\
\hline
\end{tabular}


Exhibit A1: A Plot of the Initial versus Final $O_{2}$ by Test Number

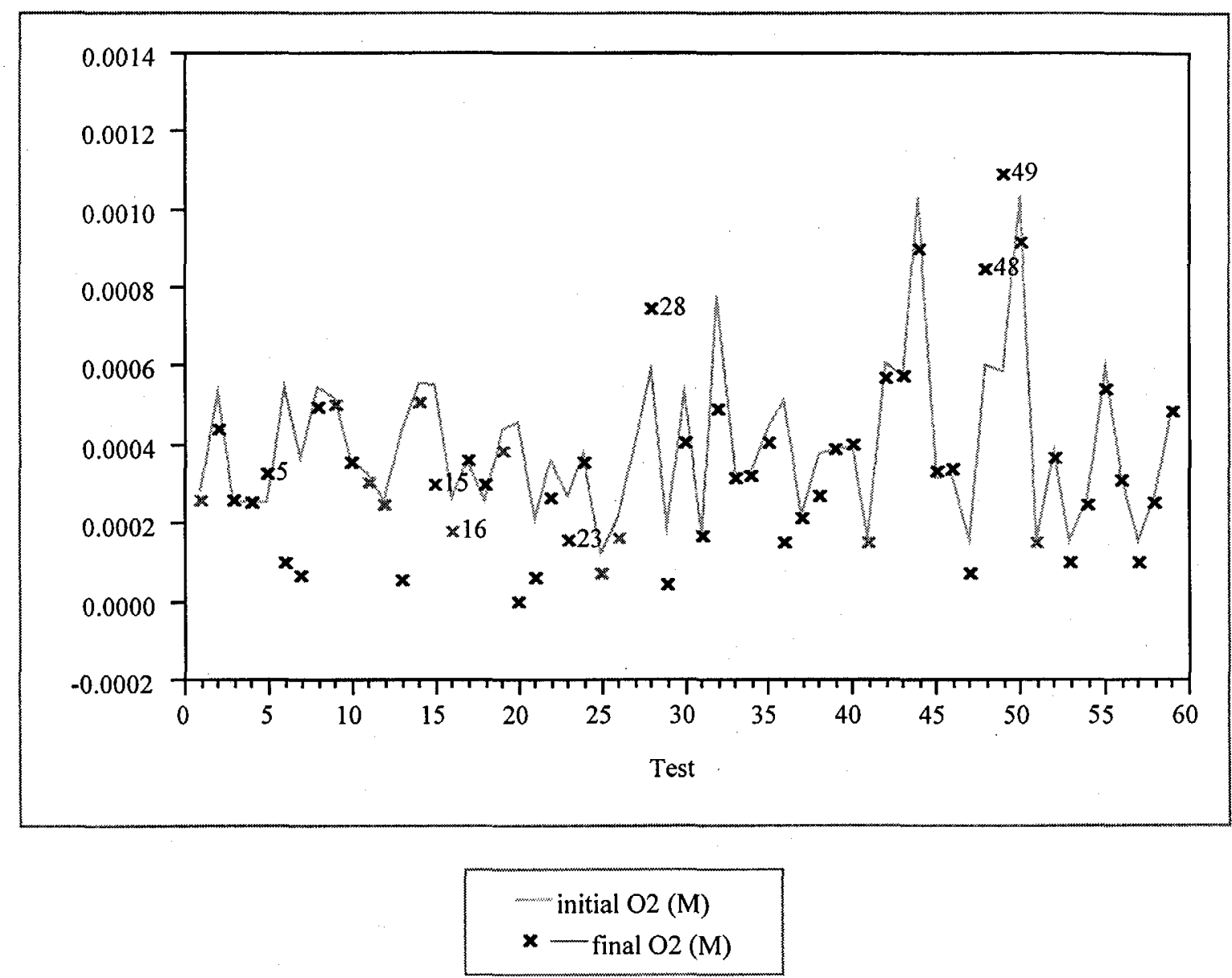


Exhibit A2: A Plot of the Change in $\mathrm{O}_{2}\left(\right.$ Delta $\left.\mathrm{O}_{2}\right)$ by Test Number

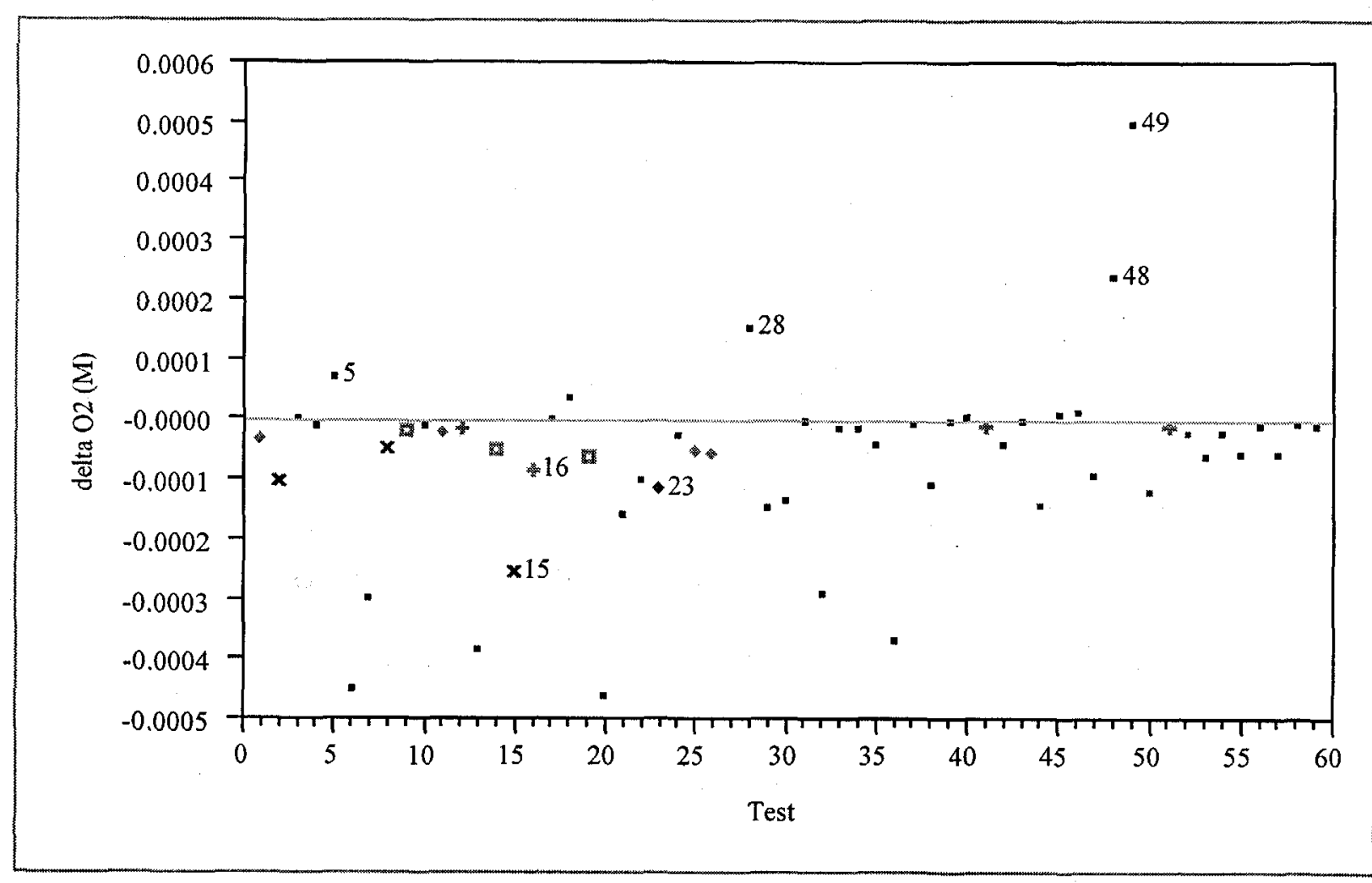

delta $\mathrm{O} 2(\mathrm{M})$

(Symbols used to identify tests as defined by the categories of Table 1) 
Exhibit A3: A Plot of the Change in $\mathrm{O}_{2}\left(\right.$ Delta $\left.\mathrm{O}_{2}\right)$ by Type Group

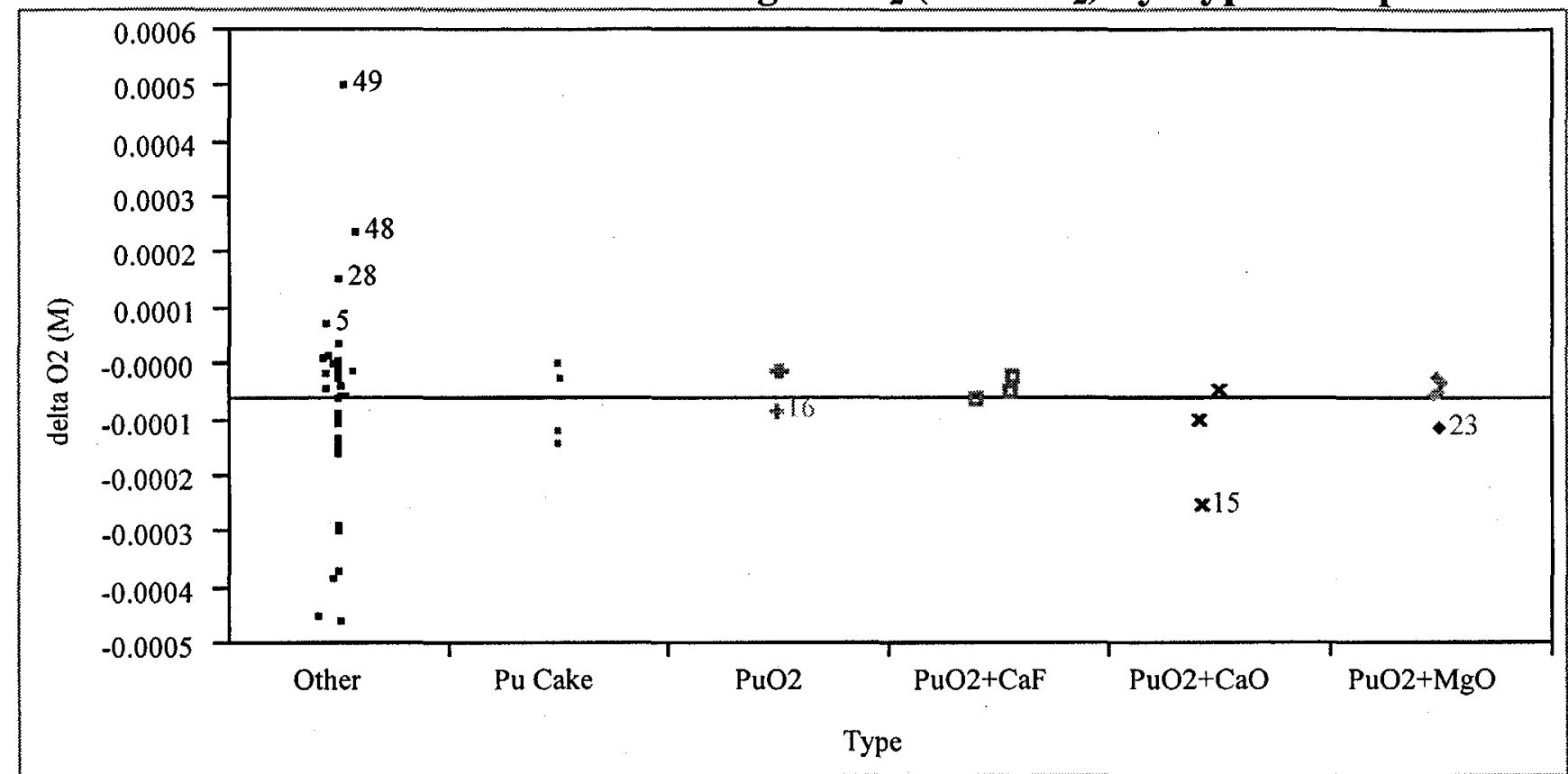

$\begin{array}{lrrrccc}\text { Level } & \text { Number } & \text { Mean } & \text { Std Dev } & \text { Number } & \text { Excluding Heated Tests } \\ \text { Other } & 39 & -0.00006 & 0.000176 & & & \text { Std Dev } \\ \mathrm{Pu} \mathrm{Cake} & 4 & -0.00007 & 0.000071 & & \\ \mathrm{PuO} 2 & 4 & -0.00003 & 0.000036 & 3 & -0.00001 & 0.000002 \\ \mathrm{PuO2}+\mathrm{CaO} & 3 & -0.00013 & 0.000107 & 2 & -0.00007 & 0.000039 \\ \mathrm{PuO}+\mathrm{CaF} & 3 & -0.00004 & 0.000022 & & & \\ \mathrm{PuO2}+\mathrm{MgO} & 5 & -0.00005 & 0.000035 & 4 & -0.00004 & 0.000015\end{array}$




\section{Exhibit A4: A Plot of the Change in $\mathrm{O}_{2}\left(\right.$ Delta $\left.\mathrm{O}_{2}\right)$ by Headspace Volume (cc)}

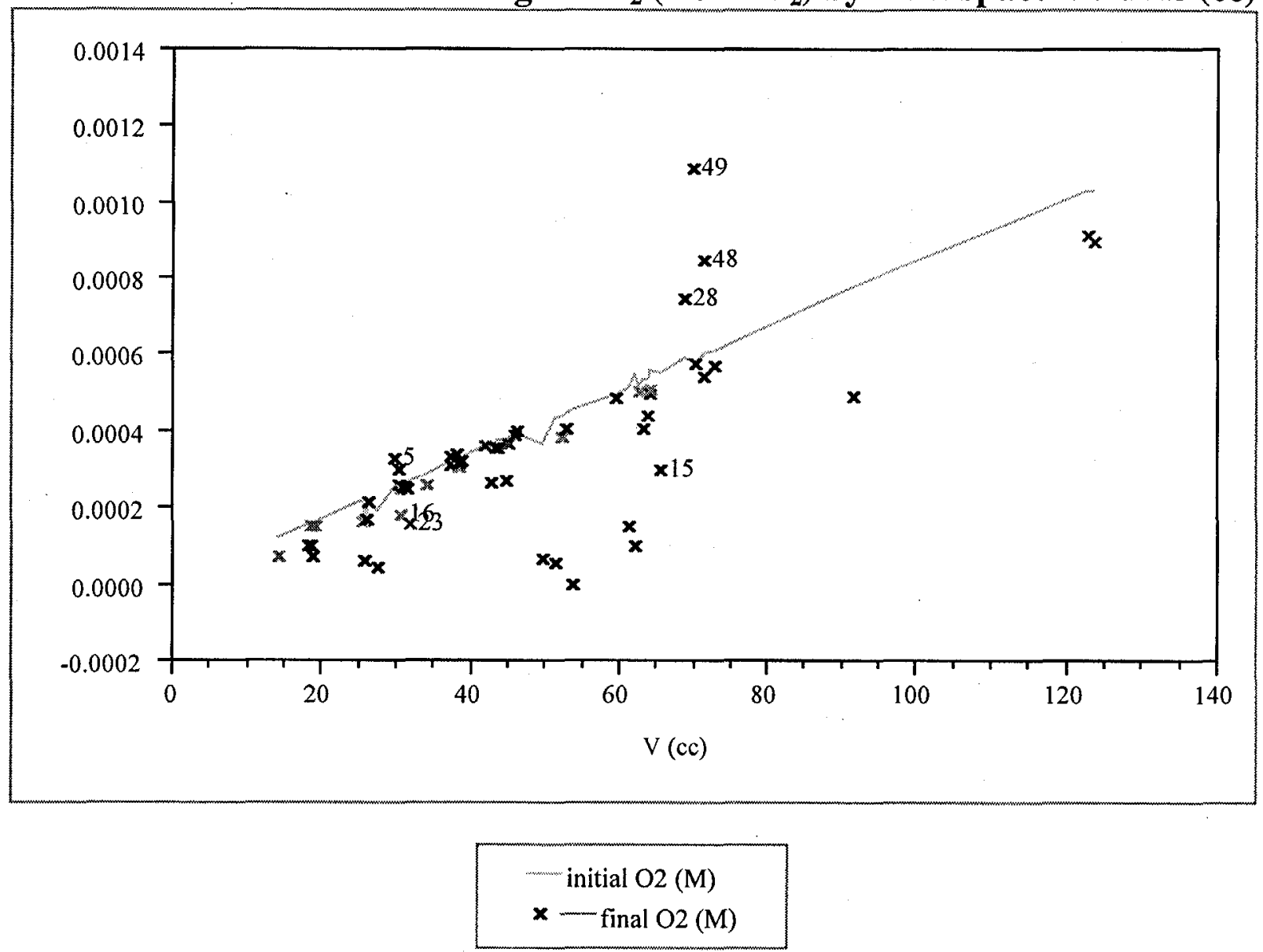

Symbols are shaded to designate the categories of Table 1 (i.e., they are shaded as in Exhibit A3). 


\section{Exhibit A5: A Plot of the Change in $\mathrm{O}_{2}\left(\right.$ Delta $\left.\mathrm{O}_{2}\right)$ by Total Sample Volume Percent}

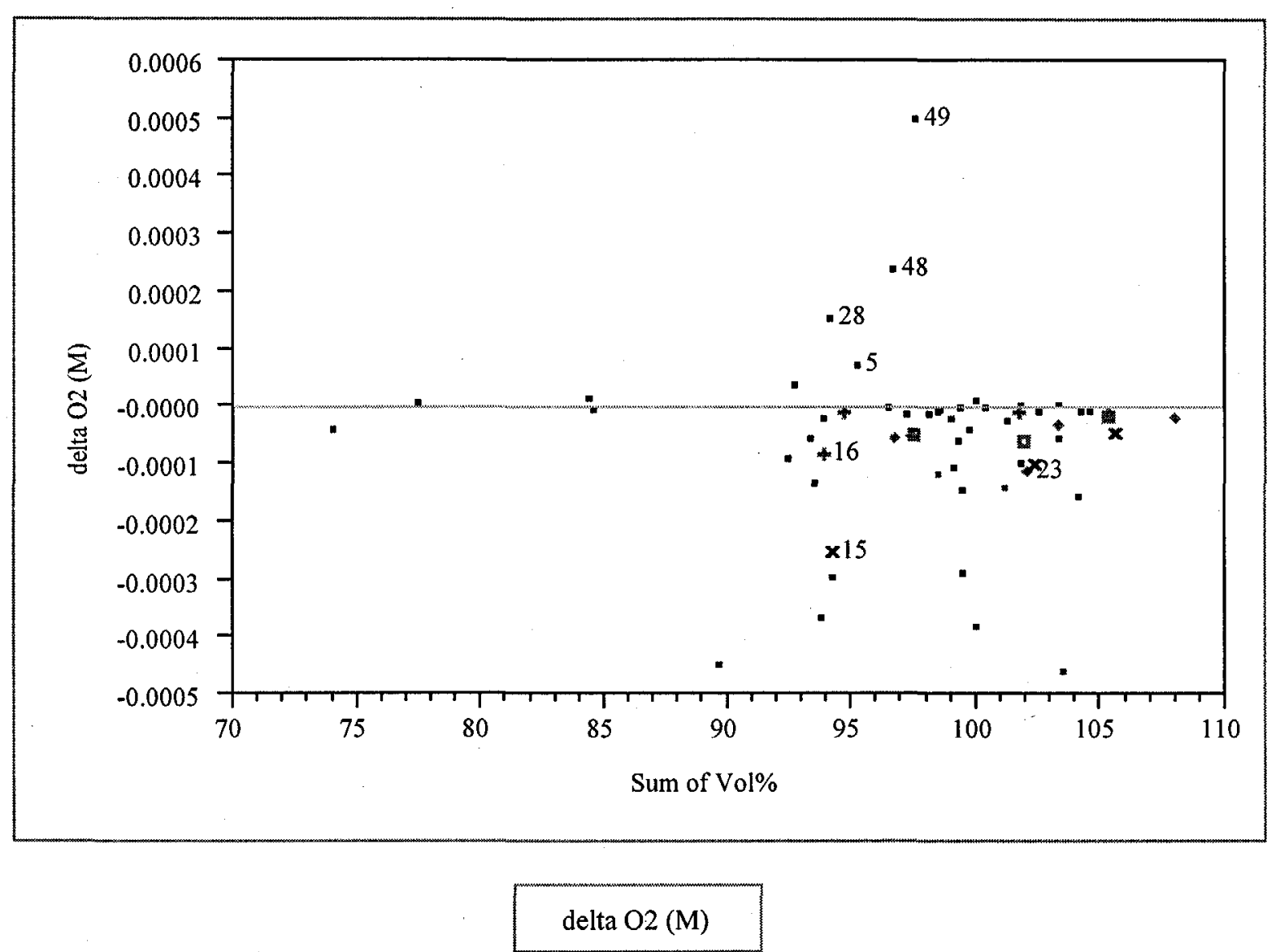

Symbols are shaded to designate the categories of Table 1 (i.e., they are shaded as in Exhibit A3). 
Exhibit A6: A Plot of the Change in $\mathrm{O}_{2}\left(\right.$ Delta $\left.\mathrm{O}_{2}\right)$ by Test Number with Bounding Uncertainties

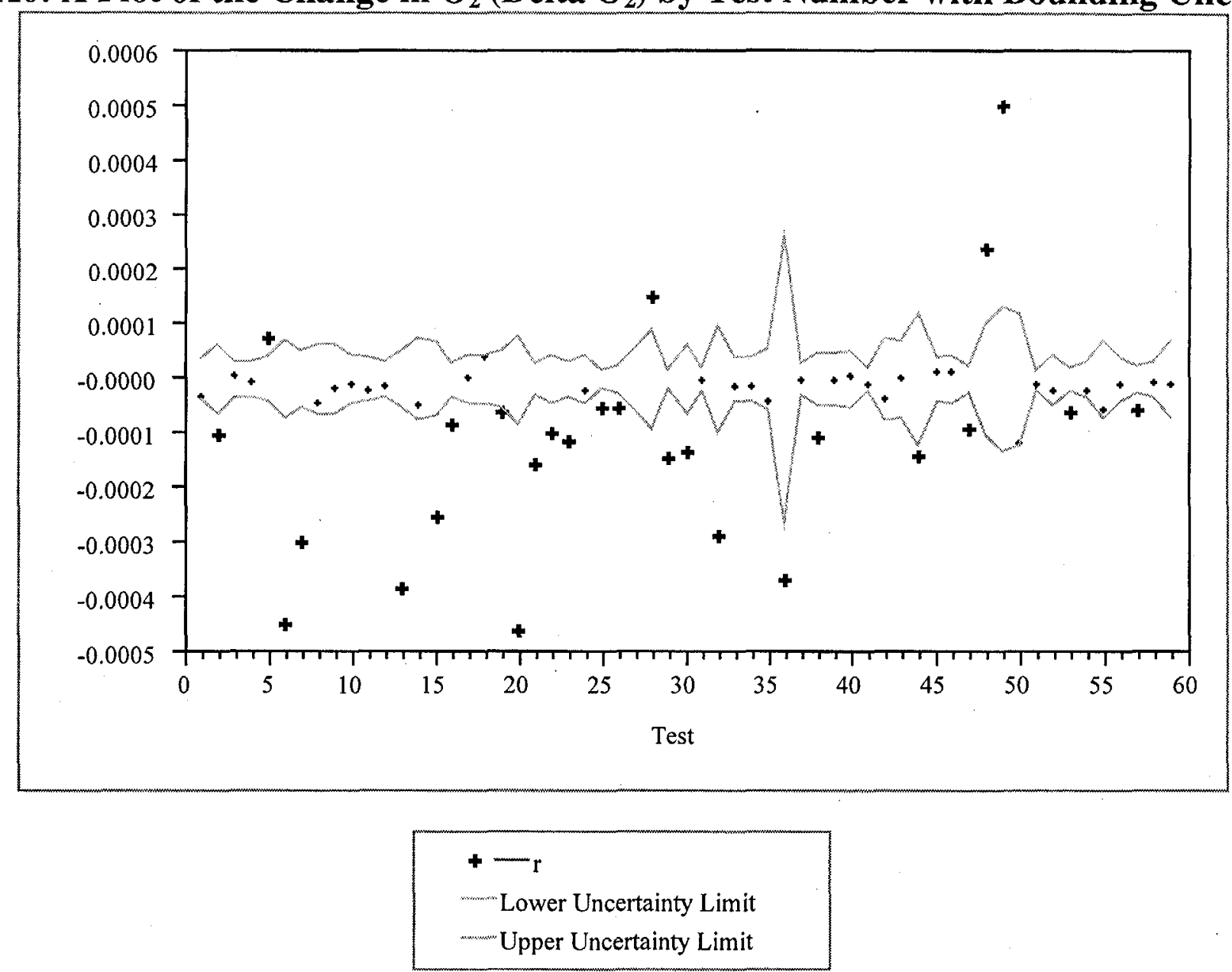

Bold symbols are used to designate statistically significant (at the $95 \%$ confidence level) test results. 
Exhibit A7: A Plot of the Change in $\mathrm{O}_{2}\left(\right.$ Delta $\left.\mathrm{O}_{2}\right)$ by Test Number with Bounding Uncertainties for Representative Tests

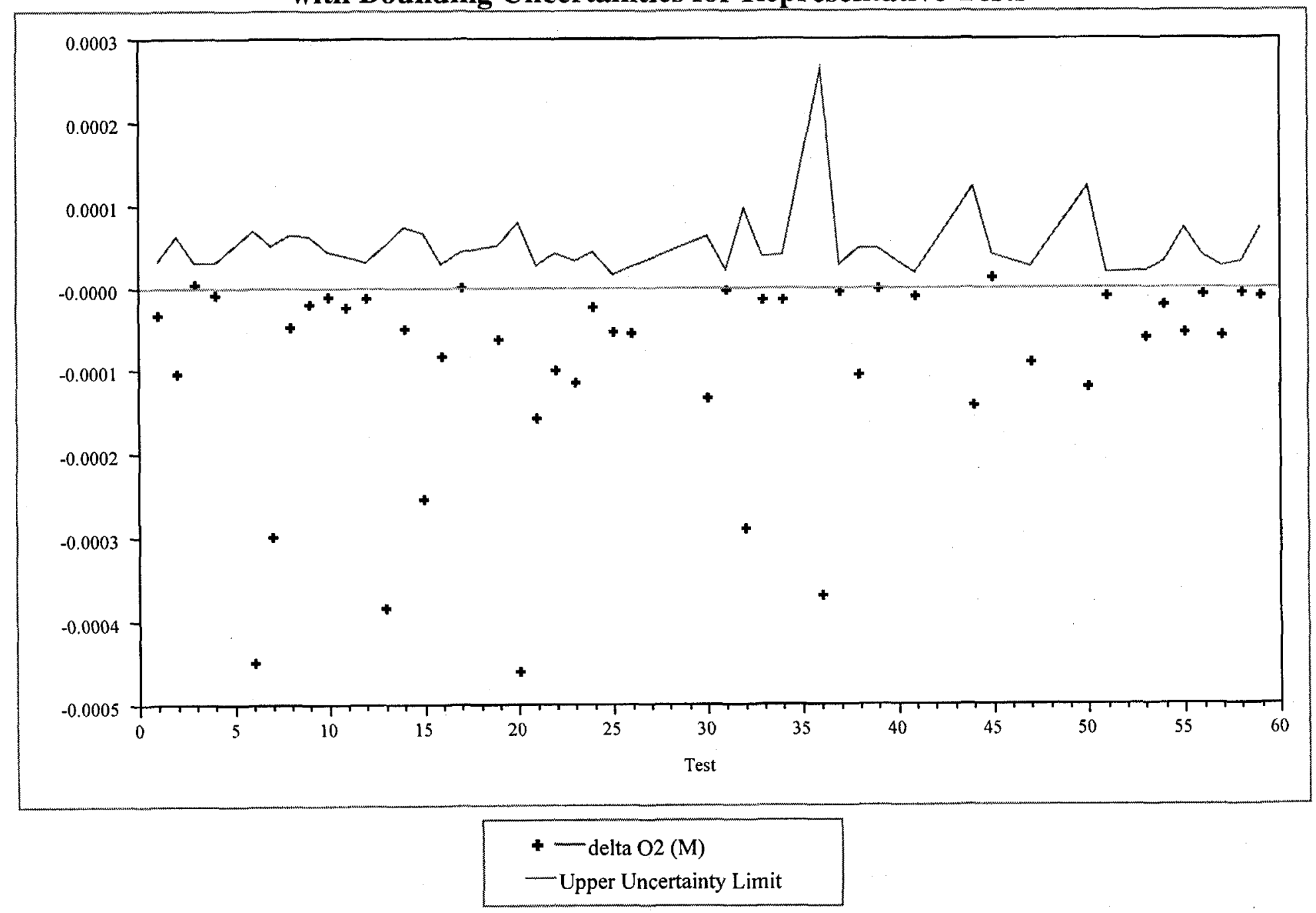




\section{Exhibit A8: A Plot of the Initial Versus Final Moles of Oxygen for Representative Tests}

initial O2 (M) By final O2 (M)

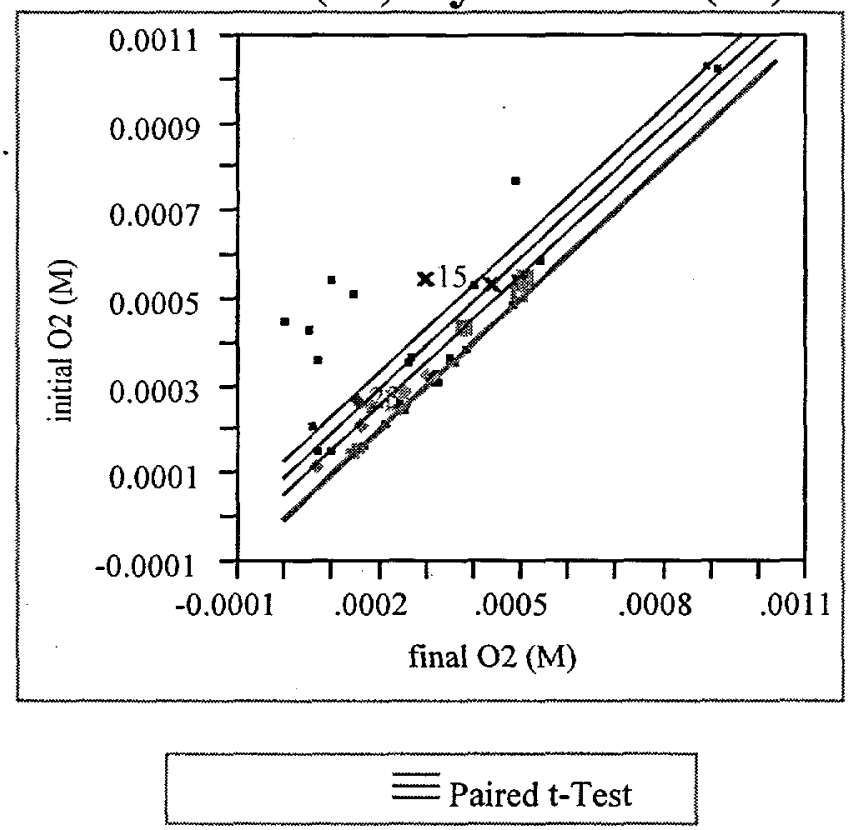

\section{Paired t-Test}

final $\mathrm{O} 2(\mathrm{M})$ - initial $\mathrm{O} 2(\mathrm{M})$

$\begin{array}{lrll}\text { Mean Difference } & -0.00009 & \text { Prob }>|\mathrm{t}| & 0.0000080 \\ \text { Std Error } & 0.000018 & \text { Prob }>\mathrm{t} & 0.9999960 \\ \text { t-Ratio } & -5.0429 & \text { Prob }<\mathrm{t} & 0.0000040 \\ \text { DF } & 45 & & \end{array}$




\section{Distribution}

N. M. Askew, 773-A

A. L. Blancett, 773-A

P. S. Blanton, 773-54A

N. E. Bibler, 773-A

M. A. Ebra, 773-42A

T. B. Edwards, $773-42 \mathrm{~A}$

F. R. Graham, 773-A

S. J. Hensel, 773-42A

S. M. King, 773-54A

R. R. Livingston, 773-A

J. E. Marra, 704-T

D. B. Moore-Shedrow, 773-A

A. M. Murray, 773-A

J. B. Shaade, 703-F

R. C. Tuckfield, 773-42A

J. H. Weber, 773-42A

J. C. Williams, 707-F

C. R. Wolfe, 773-A

D. C. Wood, 704-F

J. E. Young, 773-A 